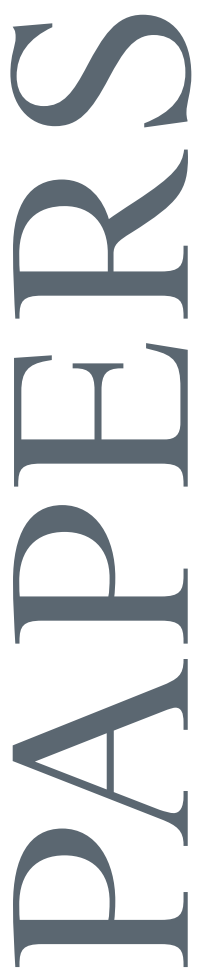

EAST-WEST CENTER WORKING PAPERS

Innovation and Economic Growth Series

No. 4, May 2015

\title{
Asian Participation and Performance at the Olympic Games
}

Marcus Noland and Kevin Stahler

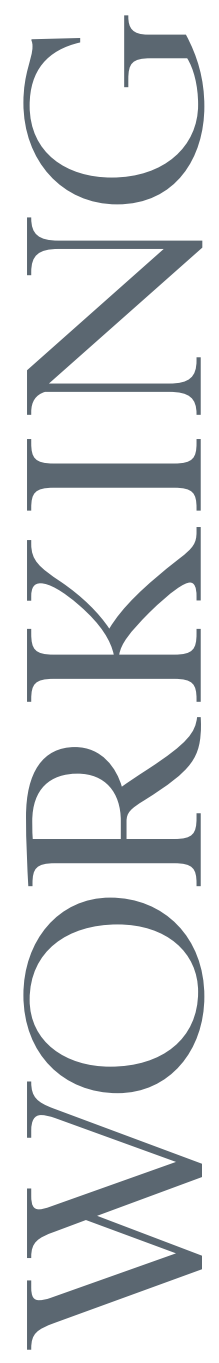

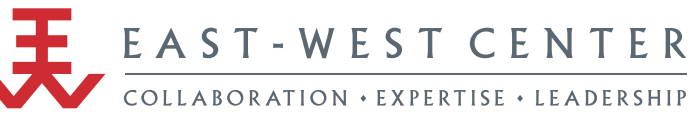




\title{
Asian Participation and Performance at the Olympic Games
}

\author{
Marcus Noland and Kevin Stahler
}

East-West Center Working Papers is an unreviewed and unedited prepublication series reporting on research in progress. The views expressed are those of the author and not necessarily those of the Center. East-West Center Working Papers are circulated for comment and to inform interested colleagues about work in progress at the Center.

Working Papers are available online for free at

EastWestCenter.org/ewcworkingpapers.

The East-West Center promotes better relations and understanding among the people and nations of the United States, Asia, and the Pacific through cooperative study, research, and dialogue. Established by the US Congress in 1960, the Center serves as a resource for information and analysis on critical issues of common concern, bringing people together to exchange views, build expertise, and develop policy options.

The Center's 21-acre Honolulu campus, adjacent to the University of Hawai'i at Mānoa, is located midway between Asia and the US mainland and features research, residential, and international conference facilities. The Center's Washington, DC, office focuses on preparing the United States for an era of growing Asia Pacific prominence.

The Center is an independent, public, nonprofit organization with funding from the US government, and additional support provided by private agencies, individuals, foundations, corporations, and governments in the region.

\section{EastWestCenter.org/publications}

Publications Office| East-West Center 1601 East-West Road | Honolulu, Hawai'i 96848-1601

Tel: 808.944.7145 | Fax: 808.944.7376

EWCBooks@EastWestCenter.org
Marcus Noland, executive vice president and director of studies, has been associated with the Peterson Institute since 1985. He is also senior fellow in the Research Program at the East-West Center.

Kevin Stahler is a research analyst with the Peterson Institute.

This paper was presented at the Asian Economic Policy Review Conference on the Sports Industry in Asia, 11 April 2015, in Tokyo, Japan. 


\title{
Asian Participation and Performance at the Olympic Games
}

\author{
Marcus Noland \\ Peterson Institute for International Economics and the East-West Center \\ 1750 Massachusetts Ave., NW. Washington, DC. 20036 \\ Tel: $1-202-328-9000$ \\ Fax: $1-202-328-5432$ \\ mnoland@petersoninstitute.org \\ Kevin Stahler \\ Peterson Institute for International Economics \\ 1750 Massachusetts Ave., NW. Washington, DC. 20036 \\ kstahler@piie.com
}

5 May 2015

\begin{abstract}
This paper examines Asian exceptionalism at the Olympics. Northeast Asian countries conform to the statistical norm while the rest of Asia lags, but this result obscures underlying distinctions. Asian women do better than men. Non-Northeast Asia's relative underperformance is due to the men. Asian performance is uneven across events, finding more success in weight-stratified contests, perhaps due to the fact that competition is more "fair" physiologically. The models imply that China, Japan, and South Korea will place among the top ten medaling countries at the 2016 Games, while China will continue to close the medal gap with the United States.
\end{abstract}

JEL: J16, L83, F69, Z13

Keywords: Asia, gender, sports, Olympics

We thank the International Olympic Committee for its provision of data used in this paper, and participants at the Asian Economic Policy Review conference on the sports industry in Asia for helpful comments on an earlier draft. 
The Olympic Games are arguably the most global organized sporting event on earth and hosting the games - whether Tokyo in 1964, Seoul in 1988, or most recently Beijing in 2008 - can powerfully convey that an emerging power has arrived on the world stage. ${ }^{1}$ As we look to the future, this message appears to be extending to an entire region: Pyeongchang, South Korea is scheduled to host the 2018 Winter Games, followed by Tokyo once again in 2020, and either Beijing or Almaty, Kazakhstan in 2022.

But the Olympics have not always been this way. Given the aristocratic perspective of its founders, it is perhaps not surprising that at the first modern Games in 1896, of the 14 participating nations that took home medals, all were European, American, or Australian men. Even immediately after World War II, the Summer Games and, especially, the Winter Games were still predominantly a showcase for European male athletic talent: At London and St. Moritz -1948, European or American men constituted 62 percent and 82 percent of total athletic participants, respectively. Tokyo's hosting of the 1964 Summer Games was notable not only because it highlighted Japan's rebirth after the devastation of World War II, but because it was also the first non-European or ex-European colony to host the Games.

Asian participation and performance have mirrored the broad patterns of internationalization at the Olympics over the past century. ${ }^{2}$ In 1912, Japan became the first Asian country to make an appearance at the Games, followed by the Philippines in 1924, and Burma (Myanmar), China, Singapore, and South Korea in 1948 (Appendix Table 1). ${ }^{3}$ In the post-War period, Asian athletic prowess continued to rise along with its growing economic power. Since the early 1980s, Asian competitors have made up roughly $11-15$ percent of the total participating athletes at the Summer Games (figure 1), and between 7 - 12 percent at the Winter Games (figure 2). Over time, however, Asian competitors have achieved greater success reaching the medal stand: at Los Angeles 1984 Asian athletes accounted for 12 percent of medals (and 14 percent of gold medals), but by 2008 they were claiming 19

\footnotetext{
${ }^{1}$ The Summer Games are officially known as the "Games of the $n$th Olympiad," and the Winter Games are the " $n$th Winter Olympics." For expository convenience we will follow the colloquial practice of referring to them as the Summer Olympics and Winter Olympics.

${ }^{2}$ This study includes 18 Asian countries in two groupings. "Northeast Asia" consists of China, Japan, and South Korea. "Other Asia" consists of Cambodia, Hong Kong, Indonesia, Laos, Malaysia, Mongolia, Burma/Myanmar, Nepal, North Korea, Philippines, Singapore, Taiwan, Thailand, TimorLeste, and Vietnam.

${ }^{3}$ During the period of Japanese colonialism, some Korean athletes competed for Japan (see Ok and Ha 2011).
} 
percent of total medals and 27 percent of the gold medals (figure 3). The improvement is even more striking in the Winter Games, with Asian athletes going from earning only a single medal in 1988 to 30 medals (12 percent of the total) in 2010 (figure 4).

Another aspect of that success is growing pluralism among Asian delegations. At Rome 1960, Japan took home 18 of 20 medals awarded to Asian countries, but by the 1980s both China and South Korea had also become formidable Olympic contenders. While these three Northeast Asian countries historically account for a lion's share of Asian medals (table 1), other Asian countries have consistently fielded about a quarter of total Asian athletes and claimed 13-16 percent of Asian medals won since the 1990s at the Summer Games (figure 5), although Asian pluralism at the Winter Olympics is still far more limited. ${ }^{4}$ Moreover, Asian female athletes have since made enormous strides from the first post-War Games, where only a single woman from an Asian country (South Korea) competed athletically at London 1948. Women have become a prominent and extremely successful component of Asia's overall performance at the Olympics (see Figures 1-4).

There is a growing body of empirical research on the Olympics: Some of this work (Bernard and Busse 2004, Johnson and Ali 2004, Lui and Suen 2008) has tested the determinants of total NOC medal outcomes at the Summer Games. Other researchers (Klein 2004, Leeds and Leeds 2012, Lowen, Deaner, Schmitt 2014, Noland and Stahler 2014) studied female athletic inclusion and success specifically. A third group of researchers have statistically modeled outcomes for individual sports (Balmer, et al. 2001, 2003, Tcha and Pershin 2003, Otamendi and Doncel 2014). However, while there is a fair amount of scholarly work devoted to the study of Asia's experience at the Olympic Games (See, for example, a compilation of work in Kelly and Brownell 2011), the empirical exploration of the region's historical performance at the Olympics is very limited. Hoffmann, et al. (2004) built econometric models and predicted medal counts for ASEAN competitors as far out as 2050. In Tcha and Pershin's (2003) study of sports-specific outcomes, the researchers included a dummy for Asian countries and found that being an Asian competitor negatively correlates

\footnotetext{
${ }^{4}$ For example, at the London 2012 Summer Games, 11 of the 18 Asian countries in our study won medals, including North Korea (6 medals), Mongolia (5 medals), and Thailand (3 medals). At the Sochi 2014 Winter Games, while a near-record-high number of participants competed from ten of the eighteen Asian countries- including the notable entry of Timor-Leste -the winner's podium was still reserved exclusively for Japan, China, and South Korea. The only other Asian country to win Olympic medals at the Winter Games is North Korea, which won one medal in 1964 and one medal in 1992.
} 
with success in swimming events, but is positively associated with weightlifting events. Hematinezhad, et al. (2011) used neural networks to predict the success of participating countries at the Asian Games, another mega-sporting event.

This paper builds on the existing literature on participation and performance in the Summer Olympics to examine the issue of Asian exceptionalism. ${ }^{5} \mathrm{We}$ find that, while in the aggregate the Northeast Asian countries conform to the statistical norm and the rest of Asia lags, these overall results obscure some interesting distinctions. Asian women generally do better than men, and non-Northeast Asia's underperformance relative to global norms is due to the men, not the women.

Similarly, Asian performance is highly uneven across events. Both Northeast and other Asia excel in badminton and table tennis, but do comparatively worse in water-based sports. Asians also exhibit somewhat better in weight class-based events, perhaps due to the fact that competition is more "fair" from a physiological standpoint.

Looking forward to the 2016 Summer Games, the models imply that China, Japan, and South Korea will continue to place among the top ten medaling countries, and China will continue to close the total medal gap with the United States.

\section{Modelling Participation and Success at the Summer Games}

Our study begins with an investigation of the historical determinants of athletic participation at the Olympics. In this regard, previous research has focused on country size, income level, and a selection of other socio-economic controls to predict how many athletes a country ultimately sends to the Games. ${ }^{6}$ Table 2 shows the determinants of an NOC's total share of Olympic participation at the Summer Olympics between 1960 and 2012 using the basic vector of controls chosen for our medaling models (discussed below). Two dummies have been added, Northeast Asia (China, Japan, and South Korea) and other Asia. Regardless of estimation technique, per capita income, population, status as a current host, status as a communist country, and average years schooling are all positive and significantly

${ }^{5}$ As a general matter, performance in the Winter Games is more idiosyncratic and in the case of Asia is completely dominated by a few countries.

${ }^{6}$ See Noland and Stahler (2014) for a detailed discussion of the determinants of female athletic representation, which also include proxies for a country's education, health, urbanization, and cultural/religious influence. 
associated with participation. The coefficients on the Northeast Asia dummy are all insignificant, but the coefficients on the rest of Asia are all significantly negative, i.e.

Northeast Asia conforms to the international norm, but the rest of Asia participates less than would be expected on the basis of standard controls.

With regard to Olympic success, we build from the canonical model articulated by Bernard and Busse (2004). Countries produce Olympic caliber athletes using people, money, and some organizational capacity using Cobb-Douglas technology,

$$
T_{i t}=f\left(N_{i t}, Y_{i t}, A_{i t}\right) \text {, }
$$

where $T$ is talent, $N$ is population, $Y$ is national income, $A$ is organizational capacity, and the subscripts $i$ and $t$ refer to country and year respectively. A country's share of Olympic medals is a function of talent, and a log function translation of talent into medal shares:

$$
E\left(\frac{\text { medals }_{i t}}{\sum_{j} \text { medals }_{j t}}\right)=M_{i t}^{*}=\mathrm{g}\left(T_{i t}\right)
$$

The following yields a specification for medal shares:

$$
M_{i t}=\left\{\begin{array}{c}
\ln A_{i t}+\gamma \ln N_{i t}+\theta \ln Y_{i t}-\ln \sum_{j} T_{j t} \text { if } M_{i t}^{*} \geq 0 \\
0 \quad \text { if } M_{i t}^{*}<0 .
\end{array}\right.
$$

Because national income can be expressed as the product of population and per capita income, the previous condition can be restated as

$$
M_{i t}=\left\{\begin{array}{cc}
C+\alpha \ln N_{i t}+\beta \ln (Y / N)_{i t}+d_{i}+v_{i}+\epsilon_{i t} & \text { if } M_{i t}^{*} \geq 0, \\
0 & \text { if } M_{i t}^{*}<0,
\end{array}\right.
$$

yielding an estimatable model

$$
M_{i t}=C+\alpha \ln N_{i t}+\beta \ln \left(\frac{Y}{N}\right)_{i t}+\text { Host }_{i t}+\text { Soviet }_{i t}+\text { Planned }_{i t}+d_{i}+v_{i}+\epsilon_{i t},
$$

where the NOC share of total medals won is a function of log population and GDP per capita, together with dummy controls for Olympic host countries and whether it was a Soviet or planned economy.

The Bernard and Busse story has intuitive explanatory power, and a country's aggregate economic resources alone appear a strong correlate of recent success for Asian NOCs (Figure 6). However, we have strong reason to believe that there are other significant 
socioeconomic and geographic determinants of medaling in the error term $\epsilon_{i t}$ that are collinear with the independent controls: for example, measures of income are also tightly correlated with educational attainment. From the selection of possible control variables shown in Appendix Table 2, we strip out correlates that offered little in the way of explanatory power and specify our core model of Olympic success at the Summer Games between 1960 and 2012:

$$
M_{i t}=C+\beta_{1} \ln N_{i t}+\beta_{2} \ln \left(\frac{Y}{N}\right)_{i t}+\beta_{3} E d u_{i t}+\beta_{4} \text { Eqdist }_{i}+\text { Host }_{i t}+
$$

PostHost $_{i t}+$ CommBloc $_{i t}+$ Boycott $_{t}+E G_{i}+$ Dope $_{i t}+$ OAsia $_{i}+$ NEAsia $_{i}+$ $\sum_{t=1960}^{2012} \delta_{t}+\epsilon_{i t}$

Where our dependent variable $M_{i t}$ indicates an individual NOC's share of total medals won out of all medals available. Our independent controls include log GDP per capita at PPP prices $\ln \left(\frac{Y}{N}\right)_{i t}$, logged population $\ln N_{i t}$, average years of total schooling among the 15+ year-old population $E d u_{i t}$, and geographical distance in degrees of latitude from the equator Eqdist ${ }_{i}$. Additionally, we include dummy variables to control for whether an NOC was the host of the Olympic games Host ${ }_{i t}{ }^{7}$ or hosted the previous Olympics PostHost ${ }_{i t}$, is a member of the communist bloc CommBloc $i t$, and whether the NOC participated in one of the major boycott years of 1980 and 1984 Boycott $_{t} .{ }^{8}$ Motivated by the finding of an extremely powerful "doping” effect for East Germany at the height of its Olympic prowess (Noland and Stahler 2014), we add a control for East Germany between 1976 and 1988 which proxies for a "doping" dummy $D o p e_{i t}$, as well as the East German fixed effect $E G_{i} .{ }^{9}$ Finally,

\footnotetext{
${ }^{7}$ In addition to the host dummy, we also tried a dummy variable for changing North-South hemispheres thereby in essence competing out of season. The results were not robust.

${ }^{8}$ For a detailed accounting of the construction of this dataset, including the integration of data on former Soviet economies, see the appendix of Noland and Stahler (2014).

${ }^{9}$ East Germany engaged in a comprehensive and invasive program of administering performance enhancing drugs (PEDs) to its Olympic athletes, particularly female competitors (Franke and Berendonk 1997, Hunt 2011, Ungerleider 2013). This program had a particularly pronounced impact 1976-1988 when the country won an astounding share of female medals (Hunt 2011). For this purpose, we estimate "doping" by giving East Germany observations a dummy which switches on in 1976, 1980, and 1988. We also separately control for the East German fixed effect, but this coefficient is not reported.
} 
we include both a dummy designating whether the NOC is a Northeast Asian country $N E A s i a_{i}$, or an other Asian country $O A s i a_{i}$, as well as whether it is.

Due to a sizable shift in the composition of Olympic competitors after the fall of the Soviet Union, as well as the expanded availability of control data, we also estimate "enhanced" models to study the determinants of success between Madrid 1992 and London 2012 .

$$
M_{i t}=C+\beta_{1} \ln N_{i t}+\beta_{2} \ln \left(\frac{Y}{N}\right)_{i t}+\beta_{3} E d u_{i t}+\beta_{4} E_{\text {qdist }}+
$$
$\beta_{5}$ LabRatio $_{i t}+\beta_{6} \ln$ ImmStock $_{i t}+$ Host $_{i t}+$ PostHost $_{i t}+$ CommBloc $_{i t}+$ OAsia $_{i}+$ $N E$ Asia $_{i}+\sum_{t=1992}^{2012} \delta_{t}+\epsilon_{i t}$

In addition to our standard controls, we also include a country's labor force gender ratio LabRatio $_{i t}$, which was found to be a positive correlate of success in previous research (Noland and Stahler 2014, Klein 2004), and the logged stock of foreign-born population In ImmStock $k_{i t}$ to test whether a country's diversity plays any role in Olympic outcomes.

Table $3.1-3.3$ show results for our core models and 3.4 - 3.6 show results for the post-1990 enhanced models. Each subset is estimated three ways: a standard tobit model with year controls, a tobit model which includes a lagged dependent variable to account for an NOC's "legacy" effect, and a random effects tobit model. Across all subsets and specifications, population, per capita income, average years schooling, and status as the current host of the Olympics are significant and positive determinants of success, just as they are for participation. In the post-1990 Games, a more evenly gender-balanced labor force also correlates with Olympic medaling, and the stock of a country's foreign born population is weakly positive only in the random effects specification (3.6). However, as with respect to the previous table on participation, the results indicate that Northeast Asia more or less conforms to the international norm, while the rest of Asia encounters decidedly less success in competition.

Next, we use specification 3.2 to generate predicted medal counts for Asian countries at the Beijing 2008 and London 2012 Games (Table 4). For most countries the predictions track the actual outcomes closely, especially for China and South Korea in both 2008 and 2012, Indonesia in 2012, and Thailand and Taiwan in 2008. However, our model does a bad job of predicting Japan's performance in these specific Games, tends to under predict Mongolian prowess, and over predicts Vietnam. Figure 7 provides a more comprehensive picture of our model's predictive power using all available Asian performances from 1960 to 
2012. In the top panel, we see that historical predictions for Northeast Asia are very accurate in most cases (correlation of 0.93 ), with only Japan significantly undershooting predictions in 1988, 1996, and 2008, which includes the Seoul and Beijing Games. ${ }^{10}$ Non-Northeast Asian countries are shown in the bottom panel. Mongolia's actual performances have consistently overshot predictions by a wide margin. Part of the explanation could be Mongolia's past communist legacy carrying over into its current performances. However, another explanation could be a cultural background that fuels its sport-specific comparative advantage: every medal Mongolia has ever won has been in a combat-related sport (wrestling, judo, boxing, shooting). Only a small number of non-Northeast Asia country observations do worse than model predictions. Many of these are Vietnam, which receives a powerful boost in the model due to its status as a communist country, but has only claimed two medals in all performances combined.

Lastly, we are interested in whether the determinants of success for Asian countries significantly differ from non-Asian countries. In table 5, for both models of participation and medaling we run dummy-continuous interaction effects on each control variable using our Asia and Northeast Asia dummies. In terms of participation, GDP per capita, education and the location of the Games in Northeast Asian venues appear to have an unusually large (and positive) impact on the numbers of Northeast Asian athletes competing. The rest of Asia appears to have an unusually low pay-off to income or population. Beyond this, there is little evidence of a distinctive Asian way in terms of medal winnings.

\section{Female Asian performance at the Summer Games}

One of the most striking aspects about Asia's performance at the Olympics is the marked success of their female athletes, especially considering its initial failure to include women athletes and the relatively low status of women in many Asian countries. Women have taken home a higher share of medals (and especially gold medals) relative to their male compatriots (see figures 1-4). The prominence of female medals winners is particularly true for China, which has specifically targeted success in women's events (Dong 2011). At

\footnotetext{
${ }^{10}$ Japan's unusually low medal haul at Beijing 2008 probably explains why it significantly overshot predictions in 2012, as a very important explanator of current medal shares in these models is a country's medal share at the previous Olympics.
} 
London 2012, Chinese athletes alone took home 58 percent of the total medals awarded to all Asian NOCs in female events (figure 8).

In table 6, we test the determinants of female medal shares specifically. ${ }^{11}$ As demonstrated in past research, while women's success is generally correlated with the same factors as male success, certain country attributes such as educational levels and status as a communist country are associated with significantly higher returns for women compared to men (Noland and Stahler 2015). While there is some evidence that both Northeast Asian women (in the full sample) and non-Northeast Asian women win comparatively fewer medals than non-Asians in standard tobit models, the lagged dependent variable and random effects specifications yield null results for both groups. Considering the past success of Northeast Asian female athletes, it may come as a surprise that, empirically, these countries exhibit no discernable difference from non-Asian countries on average. The null result on non-Northeast Asian females in the majority of models is another surprising finding. Recall that in Table 3 we uncovered a consistent and statistically significant negative return to this country grouping's total medal shares (which includes male, female, and mixed events). Yielding null results when women's events are estimated alone implies that, where male athletes in nonNortheast Asian countries may be underperforming given the model's controls, female athletes are not. $^{12}$

\section{Sport-Specific Modeling}

The analysis thus far has addressed participation and performance at the aggregate level. But the Olympics involve an enormous range of competitions, and examination of event-specific outcomes may yield additional insights.

Medal winnings have become increasingly dispersed among participating countries, especially in the Games following the dissolution of the Soviet Union (Noland and Stahler 2015). However, the degree of medal winning dispersion in general, and specifically among

${ }^{11}$ In this and subsequent "enhanced model" specifications, omit the log of a country's foreign born population, which was not robustly correlated with medaling success.

${ }^{12}$ To confirm this hypothesis, we ran regressions on specifications $6.1-6.6$ replacing femaleevent total medal shares with male-event total medal shares. Coefficients on the "Other Asia" dummy were consistently negative for both male and female medal shares. However, the dummies were statistically significant at 10 percent or below in 5 of 6 male medal share regressions, versus 2 of 6 female medal share regressions. This provides further evidence for negative returns to male athletes but not necessarily for their female counterparts. 
Asian countries, depends on the sporting category. Table 7 lists all sports at the Summer Games as of 2012 ranked according to Asian prowess, from badminton, where Asian countries accounted for 88 percent of the medals between 1960 and 2012, to equestrian and triathalon where an Asian competitor did not medal in the period surveyed. ${ }^{13}$ There is significant variation in the degree to which Asian countries have shared success in these categories (see the "concentration of winnings" column). ${ }^{14}$ For example, baseball/softball and handball are dominated by Japan and South Korea, respectively but a more diverse group of Asian countries have claimed victories in wrestling, judo, and weightlifting.

It has sometimes been argued that Asians are physiologically unsuited for certain events. Basketball and the relative dearth of tall people among Asian populations spring to mind. Table 8 reports results for the subset of events where competition is stratified by weight: boxing, judo, taekwondo, weightlifting, and wrestling. Four of the five are "combative" sports and several have a significant judged component in determining outcomes.

As seen in Table 8, there is some evidence that since 1992 Asia has does better in weight-stratified competitions. This result could be because something changed in the composition and prowess of competitors over the past 25 years; where some countries have incrementally added competitors to weight-based events, such as Thailand in weightlifting, others have reduced their presence, such as South Korea in boxing. The discrepancy may also be due to the change in the composition of non-Asian competitors like the Soviet Union, which was a formidable adversary in boxing, weightlifting, and even judo, and likely left a competition vacuum after its dissolution. Tellingly, after adding a "Soviet Union" dummy to account for its prowess in the core specifications, the coefficients for Northeast Asia became

\footnotetext{
${ }^{13}$ Japan earned a medal in an equestrian event at the 1932 Games, which is not part of our
} sample.

${ }^{14}$ To estimate medal winning concentrations among Asian countries in each sport, we use a modified version of the Herfindahl index. The Herfindahl index is commonly used in industrial organization literature to calculate the degree of intra-industry concentration among firms. The modified index proposed by Otamendi and Doncel (2014) can be written as $\sum_{i=1}^{I}\left(\frac{\left(\frac{M_{i j}}{M_{i}}\right)}{\sum_{i=1}^{I}\left(\frac{M_{i j}}{M_{i}}\right)}\right)^{2}$, where $\mathrm{i}$ is country, $\mathrm{j}$ is sport, and $\mathrm{M}$ is total medal counts. Higher values (bounded at 1) indicate higher concentrations. 
positive and statistically significant in both the tobit (8.1) and lagged dependent variable tobit (8.2) specifications. $^{15}$

In table 9 we take this analysis down to the level of specific sports. In this context, table 7 should also serve as a cautionary tale: winnings in certain sports are highly concentrated among a handful of dominant countries, and typically either China, Japan, or South Korea will claim a large portion - or even all - of the total medals awarded to Asian countries (rowing, modern pentathlon, table tennis, softball, etc.). In some cases (basketball, football, etc.) there are only three medals available per year, implying that statistical variation may be highly skewed by the idiosyncrasies of the few standouts. Therefore, we do not model sports where an Asian country did not win a medal in the sample period or cases where we have two-hundred or less usable observations from NOCs that participated in a given sporting category.

We run regressions on each sport using our core vector of controls on all available observations between 1960 and 2012. However, due to the significant data loss that would result from including lagged dependent variables, as we do our preferred total medal share model (3.2), we instead opt for a Poisson estimation using total-sport specific medals won as the regress and no LDV control. There is significant variation among the socio-economic determinants of success for each sport. For example, a country's GDP per capita is strongly positively associated with medaling in aquatics, cycling and sailing-- sports that require large capital expenditures on equipment or facilitates-- but there no discernable correlation with results in athletics. Being the Olympic host yields the strongest positive results in archery, tennis, table tennis, badminton, and judged or semi-judged sports like boxing and gymnastics. $^{16}$

Turning to Asia-specific results, in table 9 we report the coefficient and standard errors for the Other Asia and Northeast Asia dummies. Northeast Asian countries excel in sports such as archery, badminton, gymnastics, judo, and table tennis. In other cases, such as water sports, both Northeast and other Asia underperform, which would corroborate findings in Tcha and Pershin (2003). As expected, other Asia underperforms in most sports but overachieves in badminton and table tennis, where Indonesia and Malaysia (badminton) and

${ }^{15}$ The phenomenon is a weaker version of the boycott and quality of competition effect: Noland and Stahler (2014) also found compelling evidence that competition vacuums effect performance during major boycotts at the 1980/1984 Games. During boycott years, countries who participated won significantly more medals than during non-boycott years.

${ }^{16}$ For an extended discussion of the socio-economic determinants of individual sports outcomes at the gender-specific level, see Noland and Stahler (2015). 
Singapore and Taiwan (table tennis) have won multiple medals. These event-specific results also help support the results obtained in table 8: in specific events, Asians actually conform to the global norm (taekwondo, weightlifting, and wrestling) or slightly underperform (boxing). However, taken jointly as weight-based events, Asians and Northeast Asia in particular, do comparatively better on average. The modest positive results reported in table 8 , however, still could be driven by better than expected performance by Northeast Asian athletes in judo.

In Appendix Table 3, we compare model-predicted outcomes with actual outcomes for Asian countries at the London 2012 Games in fourteen sporting categories. As expected, the predictive power of the model is weaker than total aggregate medal shares (see Table 5), especially for sports like wrestling. But archery, gymnastics, and taekwondo are fairly accurately predicted, which is encouraging considering these models appear useful even without including the predictive power of a country's last performance at the Games as a regressor.

\section{Medal Forecasts}

A fairly consistent component of the literature on Olympic modeling is to apply econometric results to make out of sample forecasts (Bernard and Busse 2004, Hoffman et al. 2004, Johnson and Ali 2004, Pfau 2006, etc.). In terms of total medals won at London 2012, China $\left(2^{\text {nd }}\right)$, Japan $\left(6^{\text {th }}\right)$, and South Korea $\left(9^{\text {th }}\right)$ all performed strongly. With Asian economies exhibiting relatively strong growth, and continuing to exhibit socio-economic changes such as advances in per capita income and education, it is not unreasonable to expect that these developments will be reflected in their performances at Rio 2016.

To forecast these outcomes, we compile projections on GDP per capita (in PPP) and population growth for all available countries in 2016, the year of the next Summer Games in Brazil, from the October 2014 update of the IMF's World Economic Outlook (WEO) database (IMF 2014a, 2014b). ${ }^{17}$ Total years of average education in the population is extrapolated from the average linear growth rate between 2000 and 2010 in Barro and Lee (2013) data. Status as a communist country and distance from the equator are held constant from 2012, and the status of current host and post-host is updated to reflect that this will be

${ }^{17}$ In a January 2015 update of the WEO, the IMF reported significant downward revisions to Russian GDP growth in 2015 and 2016 (IMF 2015). However, applying updated forecasts for Russia do not affect our overall rankings forecasts. 
Brazil and Great Britain in 2016, respectively. The lagged dependent variable for 2016 forecasts is the country's total medal share at the 2012 Games.

There are six available variants of the Summer Games medaling models in table 3: a standard tobit model, a tobit model with a lagged dependent variable, and a random effects tobit model, which are estimated both within the full 1960-2012 sampling period and the "modern" 1992 - 2012 period. Forecasts were generated for the 2016 Games using the Granger-Ramanathan (1984) method. Excluding an intercept, the in-sample predicted medal shares from the six models are regressed against the actual observed medal share values, placing the constraint that the coefficients add to one:

$$
M_{-} \text {Actual }_{i t}=\beta_{1} M_{-} \text {hat } 3.1_{i t}+\ldots+\beta_{6} M_{-} \text {hat } 3.6_{i t}+\epsilon_{i t}
$$

If the resulting coefficient is negative, it is removed, and the model is re-estimated iteratively until all remaining prediction models exhibit positive coefficients that sum to one. These estimated coefficient values are then used as the weights to form the forecasts. ${ }^{18}$ In the case at hand, the process yielded a combined forecast using models 3.2 and 3.5, which were the lagged dependent variable tobit variations from the full sample and "modern" sample, respectively. ${ }^{19}$ Where:

$$
M_{-} \text {HatWeighted }{ }_{i t}=0.197 * M_{-} \text {hat } 3.2_{i t}+0.803 * M_{-} \text {hat } 3.5_{i t}
$$

Because the exact number of medals to be awarded in Rio is unknown due to added/dropped events, ties, and other factors, we report forecasted results for Asian countries

\footnotetext{
${ }^{18}$ In our case, one issue with the "modern sample"-predicted values is that, when applied to the full sample, inclusive of observations before 1990, it amounts to assuming that the coefficients on the year dummies are zero prior to 1990. Imposing this assumption generates relatively large residuals for the pre-1990 observations and could thereby downwardly bias the weight put on "modern sample" specifications. Alternatively, one could go through the Granger-Ramanathan process using all specifications, but produce predicted values only on post-1990 data. Doing this yielded a 100 percent weight on the "modern sample" lagged dependent variable tobit estimation. Ultimately, however, differences across these two sets of forecasts were minimal, as are the differences in results if full weight is placed on the "full sample" lagged dependent variable specification. In the interest of brevity, these alternate results are not shown.

${ }^{19}$ In this application, "modern" sample models do not include controls for the gender ratio or the logged stock of the immigrant population.
} 
as percentages of total medals won (table 10). ${ }^{20}$ However, in the last column we also apply these medal shares to the 962 medals awarded at the 2012 London Games to obtain forecasts of the absolute changes in medals awarded.

According to 2016 forecasts, Northeast Asia will continue to improve its performance at the Olympics. South Korea is forecasted to gain four additional medals compared to 2012's actual results; Japan will gain 3, and China 2. Moreover, in 2016 China will rise to take 9.4 percent of all medals available, up from 9.1 percent in 2012. The predicted gap between China and first-place United States is now only a matter of one percent of total medals, compared with 2012 actual results where the gap was 1.7 percent. Clearly, factors such as China's quickly rising income affect our results, but socio-economic changes within countries over the last four years do not yet appear large enough to produce major medal ranking shifts. Outside of Northeast Asia we see mostly stagnation in the performance of Asian countries, though there is a slight increase in Taiwan's predicted medal share from 2012. The model predicts Vietnam to move up significantly in the ranks and Mongolia to move down, but these countries typically exhibit large residuals - i.e. the models' ability to predict outcomes for these two countries may be modest.

The top-20 ranked countries for 2016, along with the ranking of other Asian countries, are shown in table 11 against the actual results at London $2012 .{ }^{21}$ China $\left(2^{\text {nd }}\right)$ and Japan $\left(6^{\text {th }}\right)$ maintain their 2012 rankings, though Korea $\left(10^{\text {th }}\right)$ is bumped down one rung due to the hosting advantage that propels Brazil from $15^{\text {th }}$ to $9^{\text {th }}$ place. The key takeaway here is that, even with Northeast Asia's continued gains, rankings in general will not change much.

\section{Conclusions}

The fortunes of Asia in the Olympics mirror patterns of economic development over the past century. Japan has led the way, and today participation and performance are dominated by three large Northeast Asian countries: China, Japan, and South Korea. Although these Northeast Asian countries exhibit unusually high returns on GDP per capita,

${ }^{20}$ One issue with attaining 2016 forecasts using this method is that we do not know the coefficient value for the 2016 year dummy. This is not a major issue for two reasons. First, coefficients on year dummies for recent Olympic Games are very small and not statistically significant from zero in the two models we have combined for forecasting purposes. We suspect 2016 will be similarly insignificant. Secondly, even though there could be some bias in model forecasts due to disregarding the year dummy coefficient, the bias applies equally to all 2016 values and therefore in ranked terms should not matter. 
education, and local host effects, in general Asian patterns of participation and success conform to broad global norms - there does not appear to be a uniquely "Asian way."

The overall results may obscure some interesting distinctions, however. In terms of medaling, Northeast Asia appears to conform to the international norm, while the rest of Asia lags. However, women from Asia perform as would be expected on the basis of the statistical models; it is the non-Northeast Asian men who underachieve. Indeed, overall and even for Northeast Asia, Asian women achieve better success on the medal stand than Asian men.

Likewise, these overall results mask some pronounced differences in performance across events. Both Northeast and other Asia excel in badminton and table tennis, but do comparatively worse in water-based sports. Asians also excel in weight class-based events, perhaps due to the fact that competition is more "fair" from a physiological standpoint.

Looking forward to the 2016 Summer Games, the models imply that China, Japan, and South Korea will continue to place among the top ten medaling countries. Due in part to rapidly increasing income levels, China will continue to close the medal gap with the United States, but may not yet overtake it. Although the rest of Asia continues to develop economically, it will continue to lag behind in terms of medal hauls for the foreseeable future. 


\section{References}

Balmer N.J., Nevill A.M. \& Williams A.M. (2001). Home advantage in the Winter Olympics (1908 - 1998). Journal of Sports Sciences, 19(2), 129 - 139.

Balmer N.J., Nevill A.M. \& Williams A.M. (2003). Modelling home advantage in the Summer Olympic Games. Journal of Sports Sciences, 21(6), 469 - 478.

Barro R. \& Lee J.W. (2013). A new data set of educational attainment in the world, 19502010. Journal of Development Economics, 104, 184-98.

Bernard A.B. \& Busse M.R. (2004). Who wins the Olympic Games: economic resources and medal totals. Review of Economics and Statistics, 86(1), 413-417.

Dong J. (2011). National identity, Olympic victory, and Chinese sportswomen in the global era. In: Kelly W.W. \& Brownell K. (eds.), The Olympics in East Asia: Nationalism, Regionalism, and Globalism on the Center Stage of World Sports. New Haven: Council on East Asian Studies, 161-184.

Franke W.W. \& Berendonk B. (1997). Hormonal doping and androgenization of athletes: a secret program of the German Democratic Republic Government. Clinical Chemistry, 43(7), 1262-1279.

Granger C. \& Ramanathan R. (1984). Improved methods of combining forecasts. Journal of Forecasting, 3(2): 197-204.

Hematinezhad M., Gholizadeh M.H., Ramezaniyan M., Shafiee S. \& Zahedi A.G. (2011). Predicting the success of nations in Asian Games using neural network. Sport Scientific and Practical Aspects, 8(1), 33 - 42.

Hoffman R., Lee C.G. \& Ramasamy B. (2004). Olympic success and ASEAN countries: economic analysis and policy implications. Journal of Sports Economics, 5(3), 262 276.

Hunt T. (2011). Drug Games: the International Olympic Committee and the Politics of Doping, 1960-2008. Austin, TX: University of Texas Press.

International Monetary Fund. (2014a). World Economic Outlook October 2014. "Gross domestic product based on purchasing-power-parity (PPP) per capita GDP (current International Dollar)". <http://www.imf.org/external/pubs/ft/weo/2014/02/ weodata/weoselgr.aspx > Accessed 26 February 2015. 
International Monetary Fund. (2014b). World Economic Outlook October 2014. "Population (persons)." <http://www.imf.org/external/pubs/ft/weo/2014/02/weodata/ weoselgr.aspx $>$ Accessed 26 February 2015.

International Monetary Fund. (2015). World Economic Outlook (January 2015 Update). "Cross Currents" < http://www.imf.org/external/pubs/ft/weo/2015/update/01/index.htm> Accessed 28 February 2015.

Johnson, D.K.N. \& Ali A. (2004). A tale of two seasons: participation and medal counts at the Summer and Winter Olympic Games. Social Science Quarterly, 85(4), 974-993.

Kelly W.W. \& Brownell K. (eds.). (2011). The Olympics in East Asia: Nationalism, Regionalism, and Globalism on the Center Stage of World Sports. New Haven: Council on East Asian Studies.

Klein M. (2004). Work and play: international evidence of gender equity in employment and sports. Journal of Sports Economics, 5(3), 227 - 242.

Leeds E.M. \& Leeds M.A. (2012). Gold, silver, and bronze: determining national success in men's and women's Summer Olympic events. Jahrbücher für Nationalökonomie und Statistik (Journal of Economics and Statistics), 232(3), 279 - 292.

Lowen A., Deaner R.O. \& Schmitt E. (2014). Guys and gals going for gold: the role of women's empowerment in Olympic success. Journal of Sports Economics. Published online before print 29 April. < http://jse.sagepub.com/ content/early/2014/04/28/1527002514531791.abstract> Accessed 1 March 2015.

Lui H.K. \& Suen W. (2008). Men, money, and medals: an econometric analysis of the Olympic Games. Pacific Economic Review, 13(1), 1-16.

Noland M. \& Stahler K. (2014). What goes into a medal: women's inclusion and success at the Olympic Games. Peterson Institute Working Paper Series 14-7. Washington: Peterson Institute for International Economics.

Noland M. \& Stahler K. (2015). An old boys club no more: pluralism in participation and performance at the Olympic Games, Journal of Sports Economics, forthcoming.

Ok G. \& Ha N.G. (2011). Beyond all barriers: the significance of the 1988 Seoul Olympics. In: Kelly W.W. \& Brownell K. (eds.), The Olympics in East Asia: Nationalism, Regionalism, and Globalism on the Center Stage of World Sports. New Haven: Council on East Asian Studies, 95-108. 
Otamendi J. \& Doncel L.M. (2014). Medal shares in Winter Olympic Games by sport: socioeconomic analysis after Vancouver 2010. Social Science Quarterly 95(2), 598 614.

Pfau W.D. (2006). Predicting medal wins by country at the 2006 Winter Olympic Games: an econometrics approach. Korean Economic Review, 22(2), 233 - 247.

Tcha M. \& Pershin V. (2003). Reconsidering performance at the Summer Olympics and revealed comparative advantage. Journal of Sports Economics, 4(3), 216 - 239.

Ungerleider S. (2013). Faust's Gold: Inside the East German Doping Machine, updated edition. CreateSpace Independent Publishing Platform. 


\section{Tables and Figures}

Figure 1. Asia's increased representation at the Summer Olympics

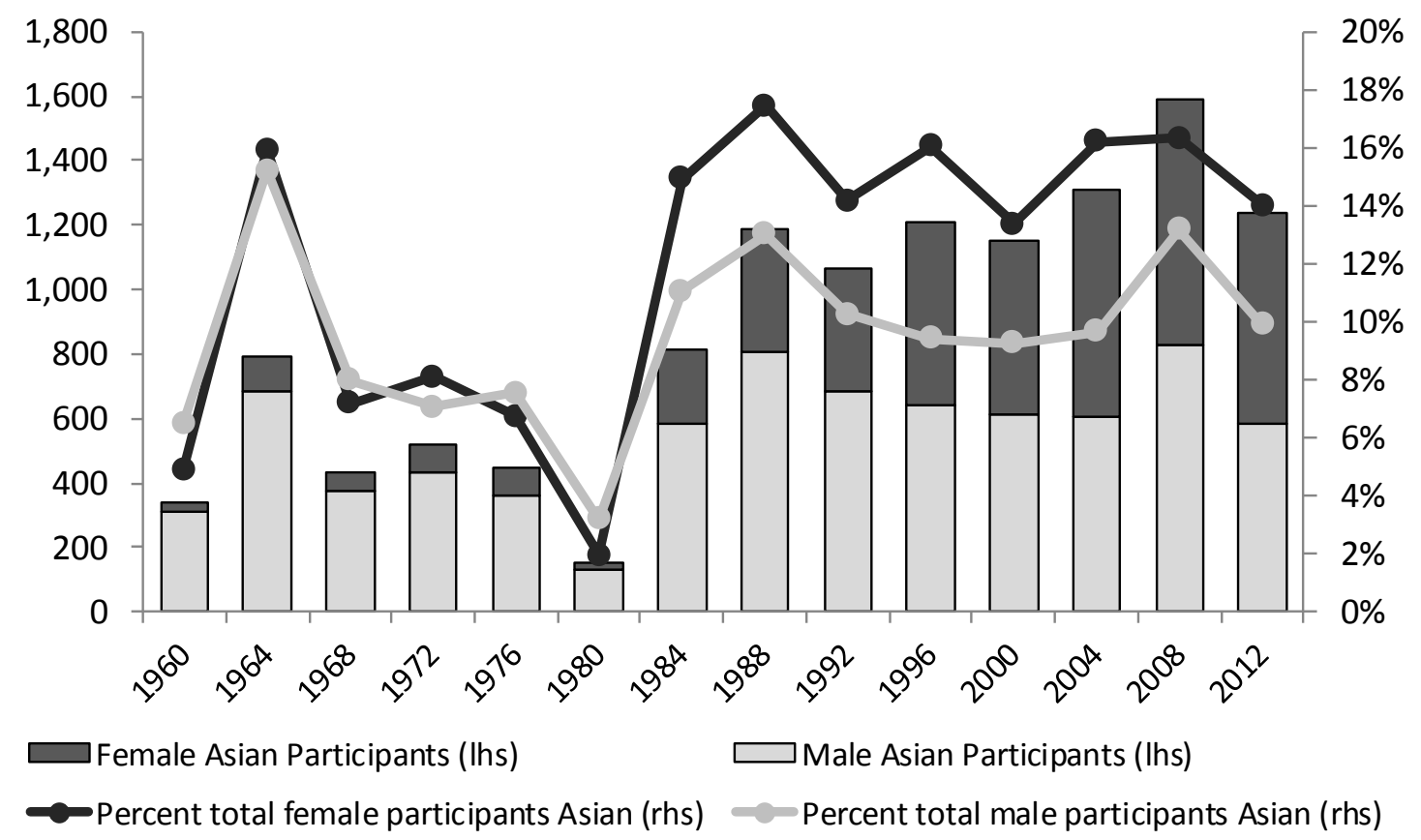

Source: International Olympic Committee 
Figure 2. Asia's representation at the Winter Olympics



Source: International Olympic Committee 
Figure 3. Asia's success at the Summer Olympics

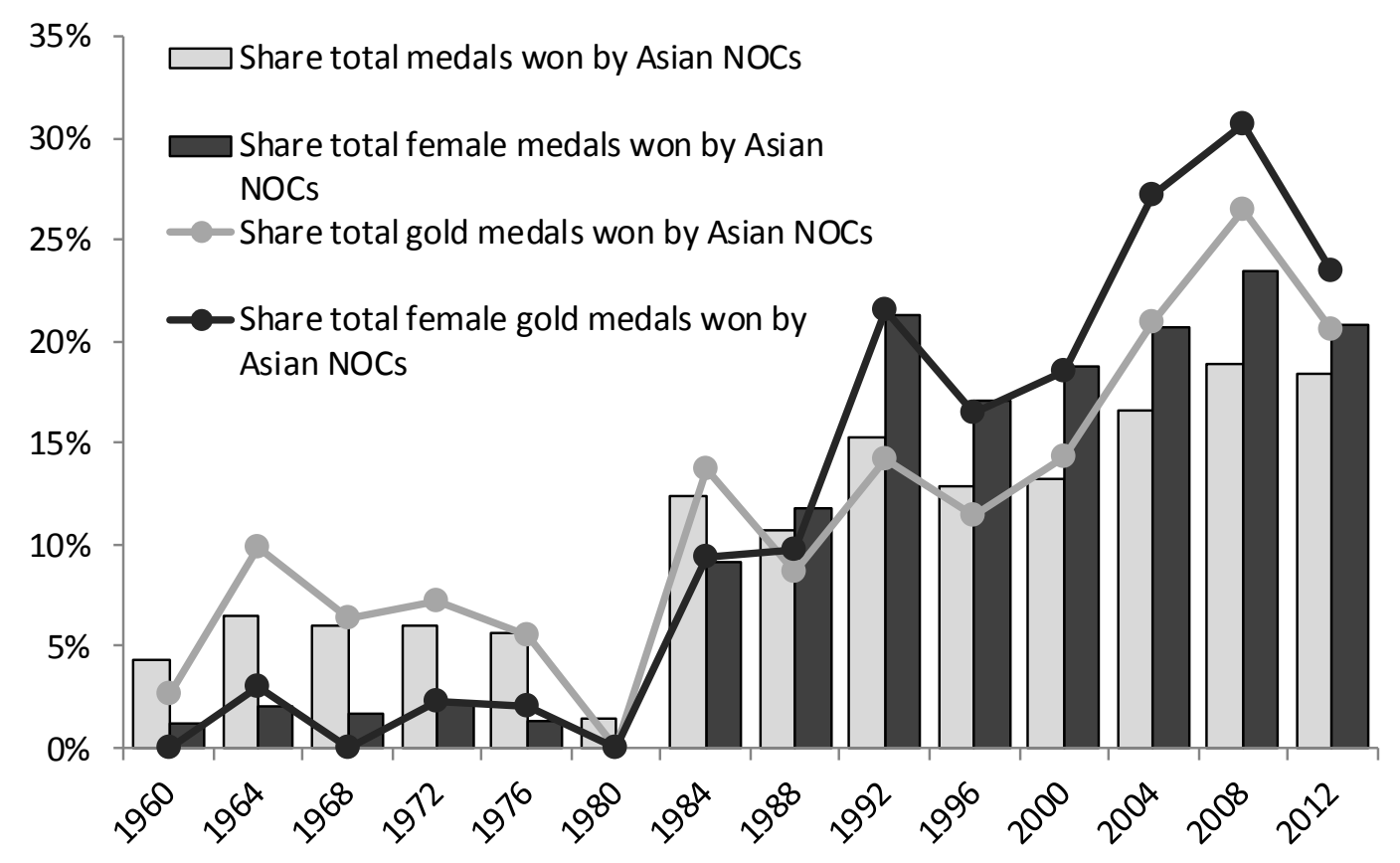

Source: International Olympic Committee 
Figure 4. Asia's success at the Winter Olympics

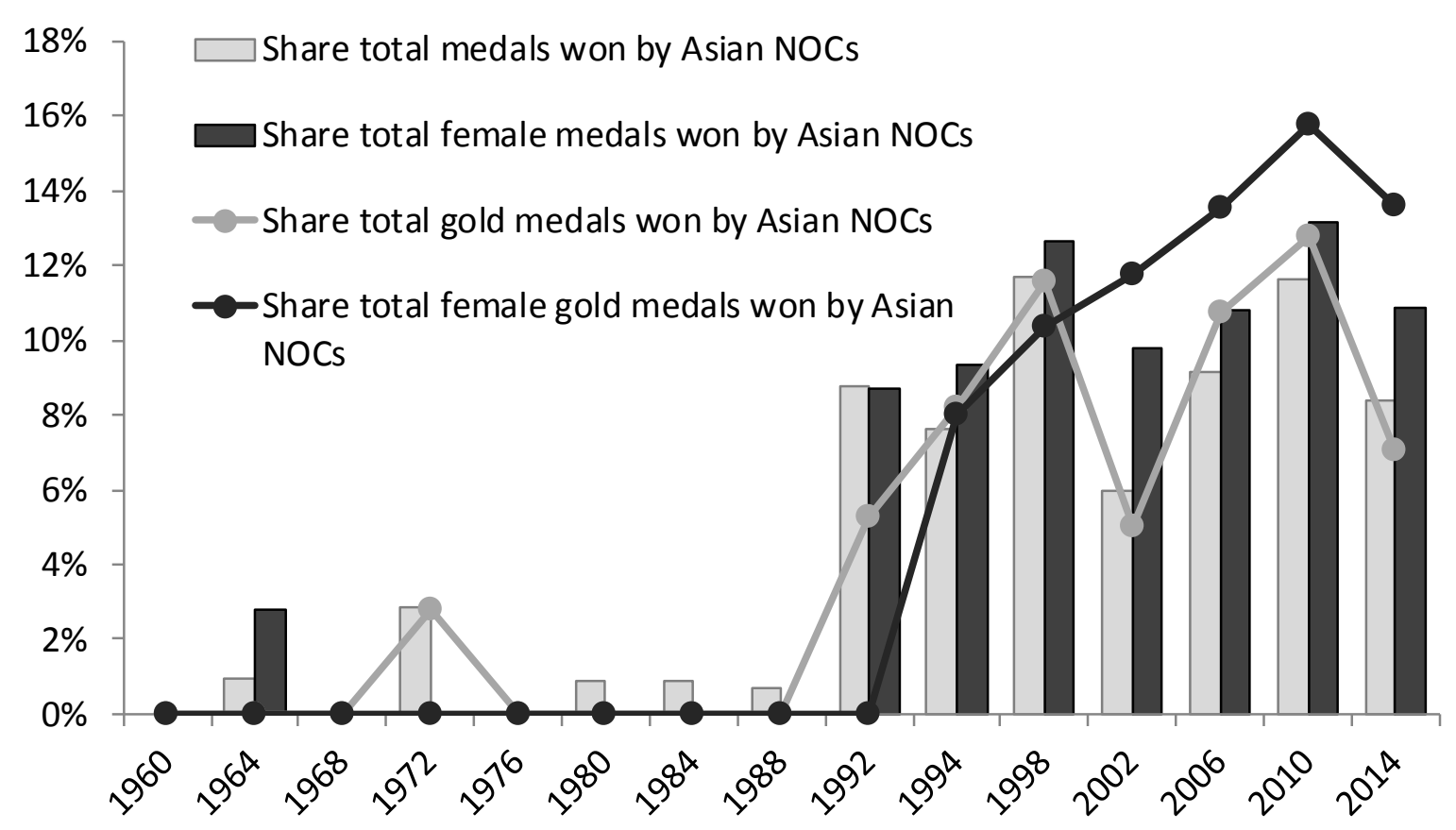

Source: International Olympic Committee 
Figure 5. Breakdown of Asian paticipants and medals at the Summer Games

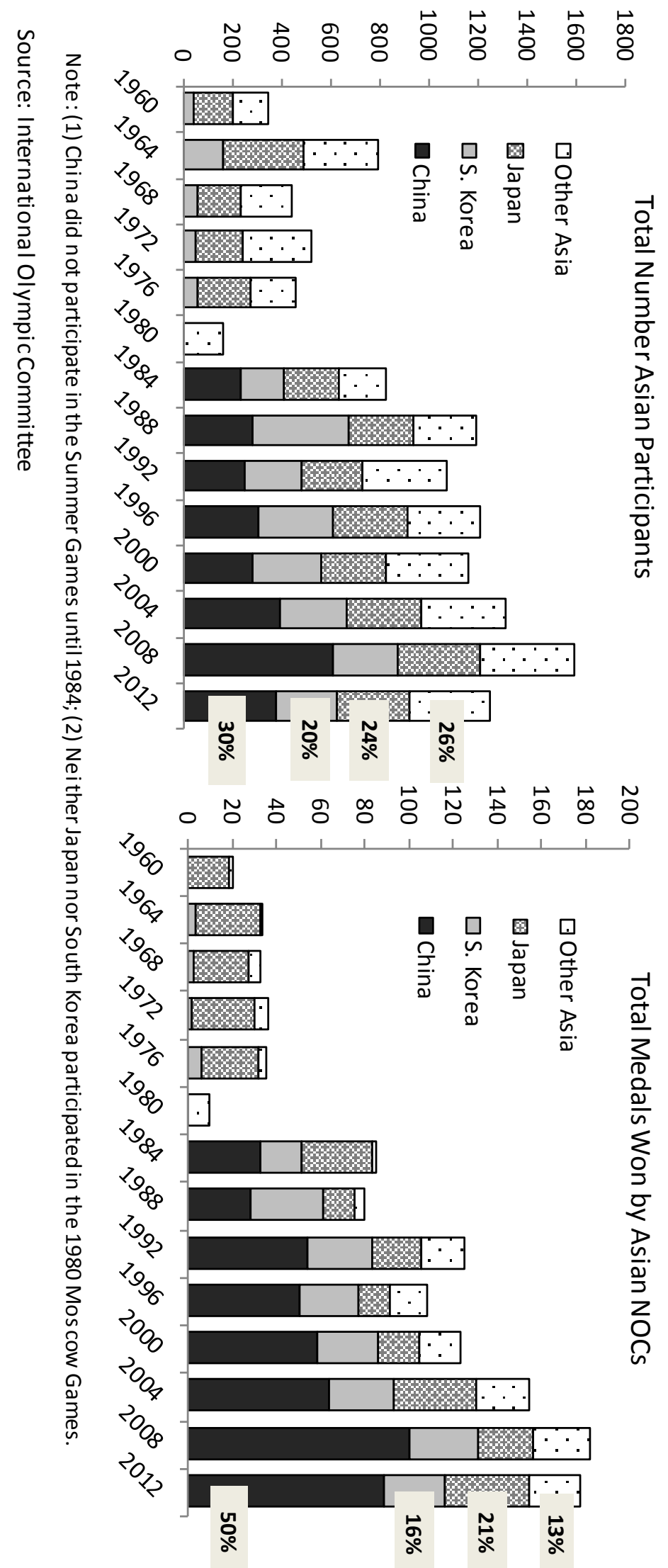


Figure 6. Relationship between total economic resources and Olympic success among Asian NOCs

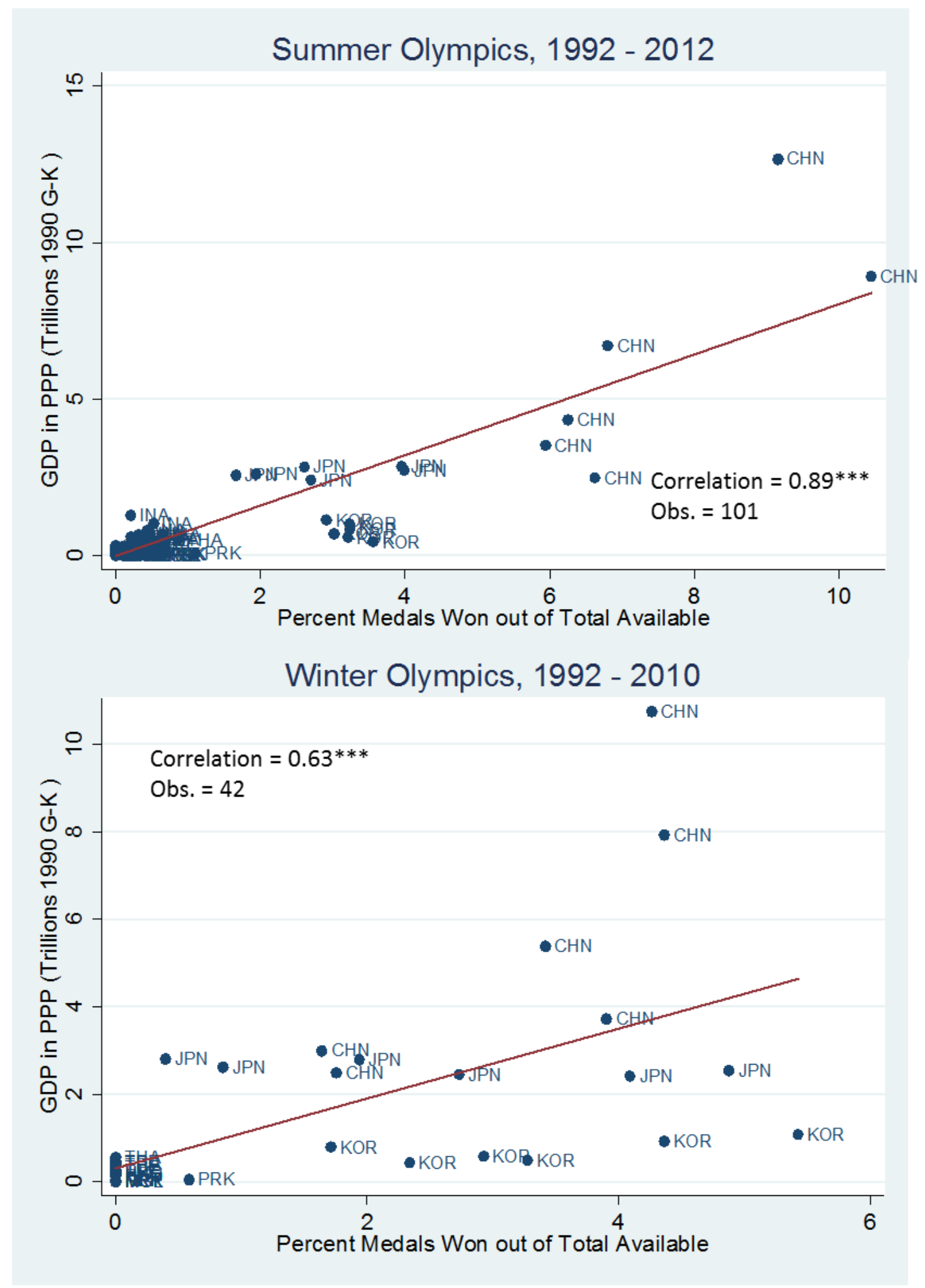

Note: See key to country abbreviations in Appendix Table 1.

Source: Maddison Tables, World Bank, International Olympic Committee 
Figure 7. Predicted Asian outcomes at the Summer Games, 1960 - 2012

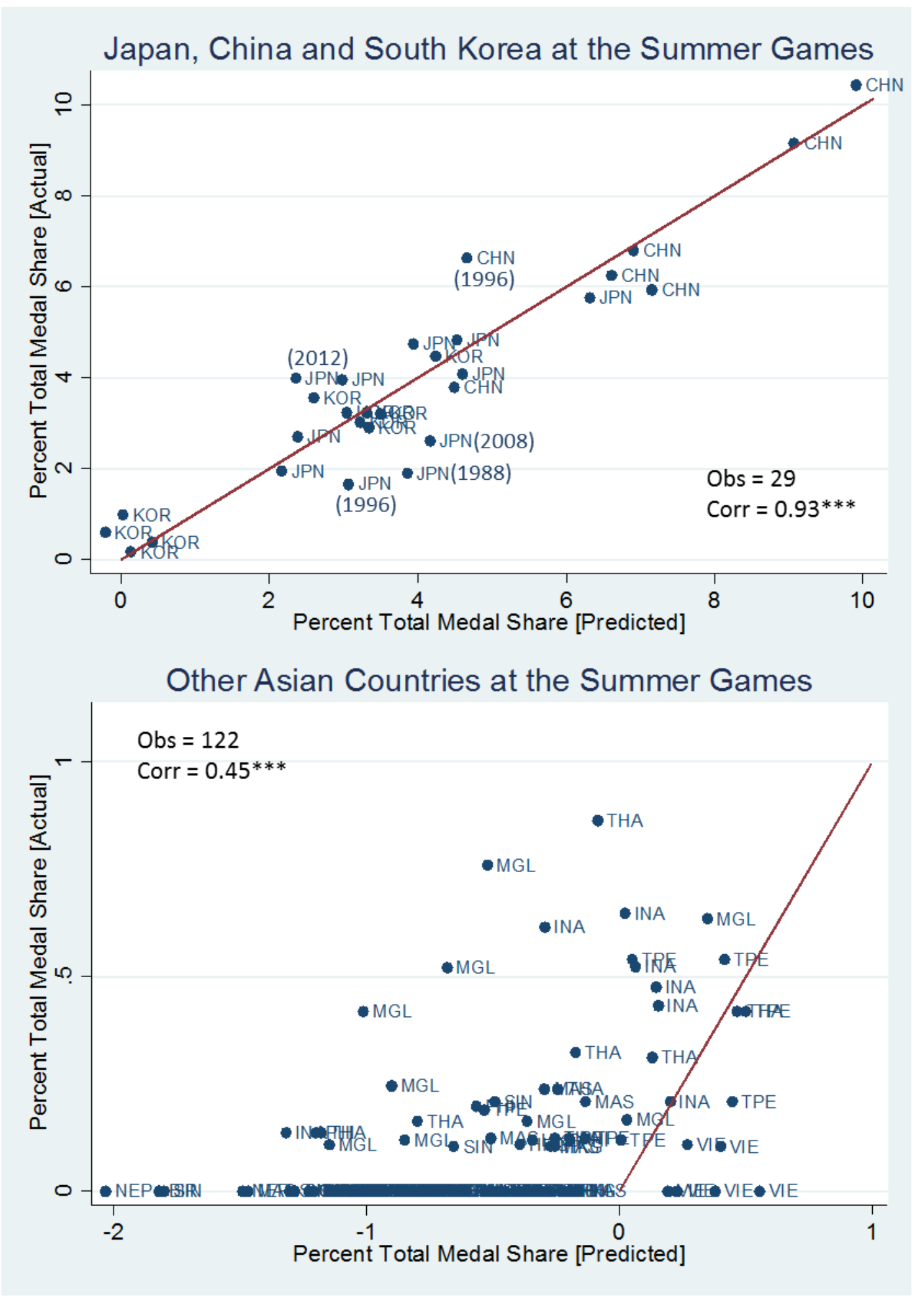

Note: (1) North Korea and Timor-Leste not predicted due to lack of data availability; (2) Predictive model used can be found in Table 3.2; (3) Diagonal line represents point at which predicted and actual outcomes are the same; (4) See key to country abbreviations in Appendix Table 1. 
Figure 8. Breakdown of total medals won by Asian NOCs in female events at the Summer Games

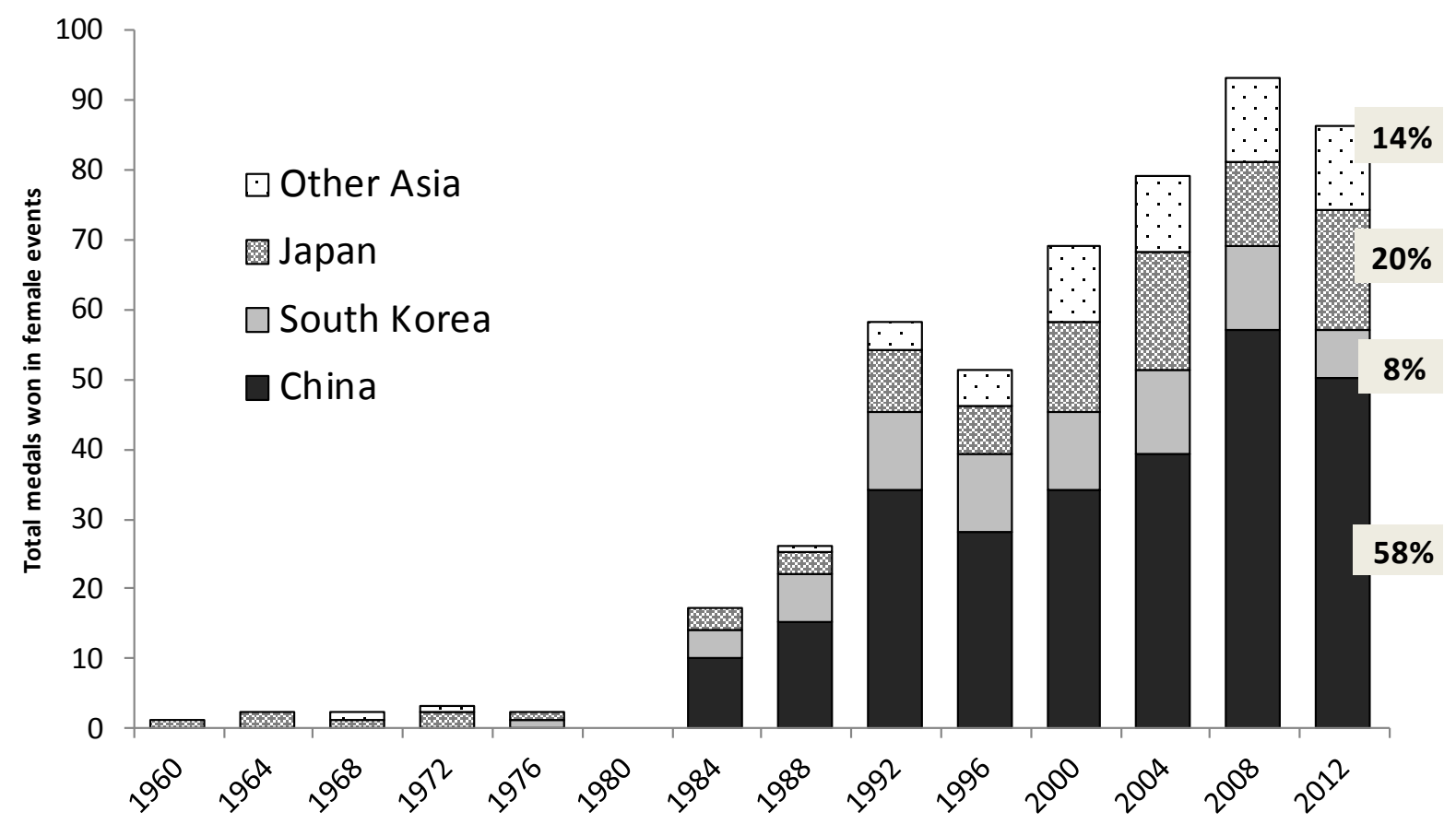

Note: (1) China did not participate in the Summer Games until 1984; (2) Neither Japan nor South Korea participated in the 1980 Moscow Games.

Source: International Olympic Committee 
Table 1. Average performance compared across Asian NOCs

\begin{tabular}{|c|c|c|c|}
\hline $\begin{array}{l}\text { National Olympic } \\
\text { Committee (NOC) }\end{array}$ & $\begin{array}{l}\text { Average Total } \\
\text { Medal Share }\end{array}$ & $\begin{array}{l}\text { Average Medals } \\
\text { per participant }\end{array}$ & $\begin{array}{c}\text { Percent Total Medals } \\
\text { Available Won between } \\
1960-2012 / 2010\end{array}$ \\
\hline \multicolumn{4}{|c|}{ All Summer Games Events, 1960 - 2012} \\
\hline China & $6.7 \%$ & 0.18 & $4.6 \%$ \\
\hline Japan & $3.6 \%$ & 0.10 & $3.2 \%$ \\
\hline South Korea & $2.2 \%$ & 0.08 & $2.3 \%$ \\
\hline North Korea & $0.7 \%$ & 0.12 & $0.5 \%$ \\
\hline Mongolia & $0.3 \%$ & 0.08 & $0.2 \%$ \\
\hline Indonesia & $0.3 \%$ & 0.07 & $0.3 \%$ \\
\hline Thailand & $0.2 \%$ & 0.05 & $0.2 \%$ \\
\hline Taiwan & $0.2 \%$ & 0.03 & $0.2 \%$ \\
\hline Malaysia & $0.1 \%$ & 0.02 & $0.1 \%$ \\
\hline Philippines & $0.04 \%$ & 0.01 & $0.04 \%$ \\
\hline Singapore & $0.04 \%$ & 0.03 & $0.04 \%$ \\
\hline Hong Kong & $0.03 \%$ & 0.01 & $0.03 \%$ \\
\hline Vietnam & $0.02 \%$ & 0.02 & $0.02 \%$ \\
\hline \multicolumn{4}{|c|}{ All Winter Games Events, 1960 - 2010} \\
\hline China & $2.1 \%$ & 0.08 & $2.0 \%$ \\
\hline Japan & $1.4 \%$ & 0.03 & $1.7 \%$ \\
\hline South Korea & $1.4 \%$ & 0.09 & $2.1 \%$ \\
\hline North Korea & $0.2 \%$ & 0.02 & $0.1 \%$ \\
\hline
\end{tabular}

Notes: (1) Cambodia, Timor-Leste, Laos, Myanmar, and Nepal participated in the Summer Games at points between 1960 and 2012, but have yet to win a medal; (2) Taiwan, Hong Kong, Mongolia, Nepal, the Philippines, and Thailand participated in the Winter Games at points between 1960 - 2010, but have yet to win a medal.

Source: International Olympic Committee 
Table 2. Determinants of participation at the Summer Olympic Games, 1960 - 2012

\begin{tabular}{|c|c|c|c|c|}
\hline \multirow{2}{*}{ Total Participation Share } & $(2.1)$ & $(2.2)$ & (2.3) & $(2.4)$ \\
\hline & OLS & $\begin{array}{l}\text { Full Instrument System } \\
\text { GMM (Lags 3+) }\end{array}$ & $\begin{array}{l}\text { Restricted Instrument } \\
\text { System GMM (Lag } 3 \\
\text { Only) }\end{array}$ & $\begin{array}{l}\text { Collapsed } \\
\text { Instrument System } \\
\text { GMM }\end{array}$ \\
\hline \multirow[t]{2}{*}{ Log GDP per capita (1990 G-K \$I) } & $0.176^{* * *}$ & $0.0562^{* *}$ & $0.110^{* *}$ & $0.174^{\star *}$ \\
\hline & $(0.0240)$ & $(0.0265)$ & $(0.0488)$ & $(0.0702)$ \\
\hline \multirow[t]{2}{*}{ Log population } & $0.397^{\star * *}$ & $0.140^{* * *}$ & $0.262^{* *}$ & $0.424^{* * *}$ \\
\hline & $(0.0208)$ & $(0.0491)$ & $(0.113)$ & $(0.0959)$ \\
\hline \multirow[t]{2}{*}{ Current Host } & $3.363^{* * *}$ & $2.662^{* * *}$ & $2.744^{* * *}$ & $3.120^{\star * *}$ \\
\hline & $(0.212)$ & $(0.266)$ & $(0.312)$ & $(0.346)$ \\
\hline \multirow[t]{2}{*}{ Communist Bloc } & $0.959^{* * *}$ & $0.584^{* * *}$ & $0.795^{\star \star *}$ & $1.163^{* \star *}$ \\
\hline & $(0.107)$ & $(0.158)$ & $(0.255)$ & $(0.302)$ \\
\hline \multirow[t]{2}{*}{ Average years total schooling } & $0.132^{* \star *}$ & $0.0494^{* *}$ & $0.0875^{* *}$ & $0.142^{* * *}$ \\
\hline & $(0.0132)$ & $(0.0208)$ & $(0.0430)$ & $(0.0427)$ \\
\hline \multirow[t]{2}{*}{ Distance From Equator } & $0.00999^{* * *}$ & $0.00360^{*}$ & $0.00730^{*}$ & $0.0116^{* *}$ \\
\hline & $(0.00138)$ & $(0.00198)$ & $(0.00393)$ & $(0.00553)$ \\
\hline \multirow[t]{2}{*}{ Northeast Asia Dummy } & 0.0269 & -0.200 & -0.121 & 0.0538 \\
\hline & $(0.137)$ & $(0.152)$ & $(0.265)$ & $(0.407)$ \\
\hline \multirow[t]{2}{*}{ Other Asia Dummy } & $-0.632^{* * *}$ & $-0.251^{* * *}$ & $-0.442^{* *}$ & $-0.686^{* * *}$ \\
\hline & $(0.0476)$ & $(0.0791)$ & $(0.172)$ & $(0.173)$ \\
\hline \multirow[t]{2}{*}{ T-1 Lagged Dependent Variable } & & $0.480^{* \star *}$ & 0.361 & -0.176 \\
\hline & $\mathrm{n} / \mathrm{a}$ & $(0.108)$ & $(0.270)$ & $(0.191)$ \\
\hline \multirow[t]{2}{*}{ T-2 Lagged Dependent Variable } & $\mathrm{n} / \mathrm{a}$ & $0.145^{\star *}$ & -0.0415 & 0.0866 \\
\hline & $\mathrm{n} / \mathrm{a}$ & $(0.0586)$ & $(0.0746)$ & $(0.0929)$ \\
\hline \multirow[t]{2}{*}{ Constant } & $-7.442^{* * *}$ & $-3.042^{* * *}$ & $-5.712^{\star *}$ & $-9.199^{\star * *}$ \\
\hline & $(0.386)$ & $(0.992)$ & $(2.293)$ & $(1.903)$ \\
\hline Observations & 1,440 & 1,027 & 1,027 & 1,027 \\
\hline Unique Country Groups & $\mathrm{n} / \mathrm{a}$ & 135 & 135 & 135 \\
\hline R-Squared & 0.709 & $\mathrm{n} / \mathrm{a}$ & $\mathrm{n} / \mathrm{a}$ & $\mathrm{n} / \mathrm{a}$ \\
\hline Time Controls & Yes & Yes & Yes & Yes \\
\hline Country Controls & No & Yes & Yes & Yes \\
\hline Number of Instruments & $\mathrm{n} / \mathrm{a}$ & 97 & 42 & 32 \\
\hline $\begin{array}{l}\text { Arellano-Bond test for } A R(2) \text { in first } \\
\text { differences ( } p \text {-value) }\end{array}$ & $\mathrm{n} / \mathrm{a}$ & 0.345 & 0.108 & 0.915 \\
\hline $\begin{array}{l}\text { Hansen test of overriding restrictions } \\
\text { (p-value) }\end{array}$ & $\mathrm{n} / \mathrm{a}$ & 0.062 & 0.149 & 0.534 \\
\hline
\end{tabular}

Notes: (1) Robust standard errors in parentheses ${ }^{* * *} p<0.01,{ }^{* *} p<0.05,{ }^{*} p<0.1$; (2) A dummy variable for the boycotted $1980 / 1984$ games is also included in all regressions, but not reported. 
Table 3. Determinants of success at the Summer Olympic Games, 1960 - 2012

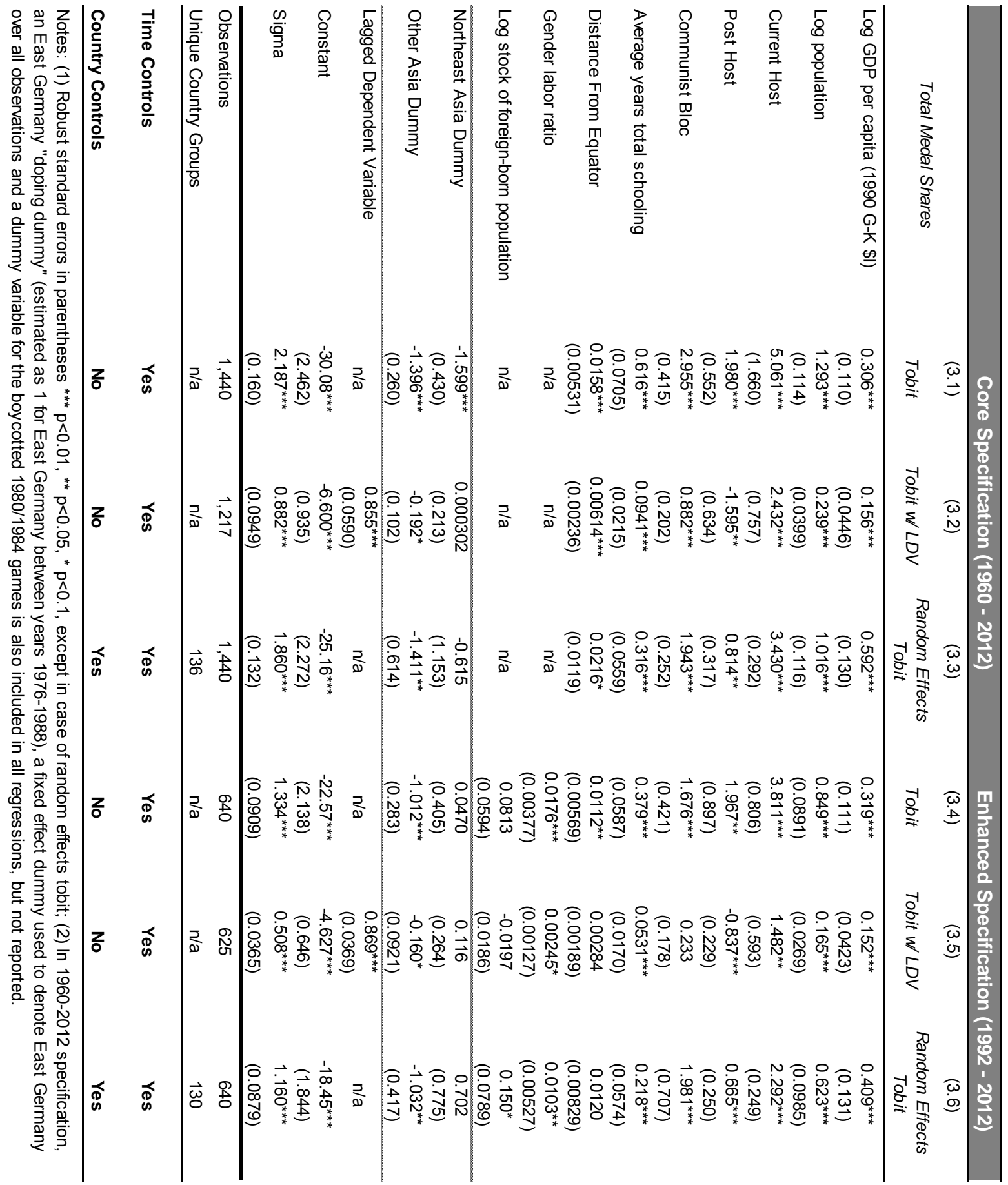


Table 4. Actual versus predicted total medal counts at Beijing and London

\begin{tabular}{lcccc}
\hline & \multicolumn{2}{c}{ Beijing - 2008 } & \multicolumn{2}{c}{ London - 2012 } \\
\hline \multicolumn{1}{c}{ Country } & Actual Count & Predicted Count & Actual Count & Predicted Count \\
\hline Cambodia & 0 & 0 & 0 & 0 \\
Taiwan & 4 & 5 & 2 & 4 \\
Hong Kong & 0 & 0 & 1 & 0 \\
Indonesia & 5 & 1 & 2 & 2 \\
Japan & 25 & 40 & 38 & 29 \\
Laos & 0 & 0 & 0 & 0 \\
Malaysia & 1 & 0 & 2 & 0 \\
Mongolia & 4 & 0 & 5 & 0 \\
Myanmar & 0 & 0 & 0 & 0 \\
Nepal & 0 & 0 & 0 & 0 \\
PR China & 100 & 95 & 88 & 87 \\
Philippines & 0 & 0 & 0 & 0 \\
Republic of Korea & 31 & 32 & 28 & 32 \\
Singapore & 1 & 0 & 2 & 0 \\
Thailand & 4 & 4 & 3 & 1 \\
Vietnam & 1 & 4 & 0 & 5 \\
\hline
\end{tabular}

Note: (1) North Korea and Timor-Leste not predicted due to lack of data availability; (2) Predictive model used can be found in Table 3.2; (3) All model-predicted negative outcomes are shown as zero on table. 
Table 5. Interaction effects for Asian competitors on core Summer Games models

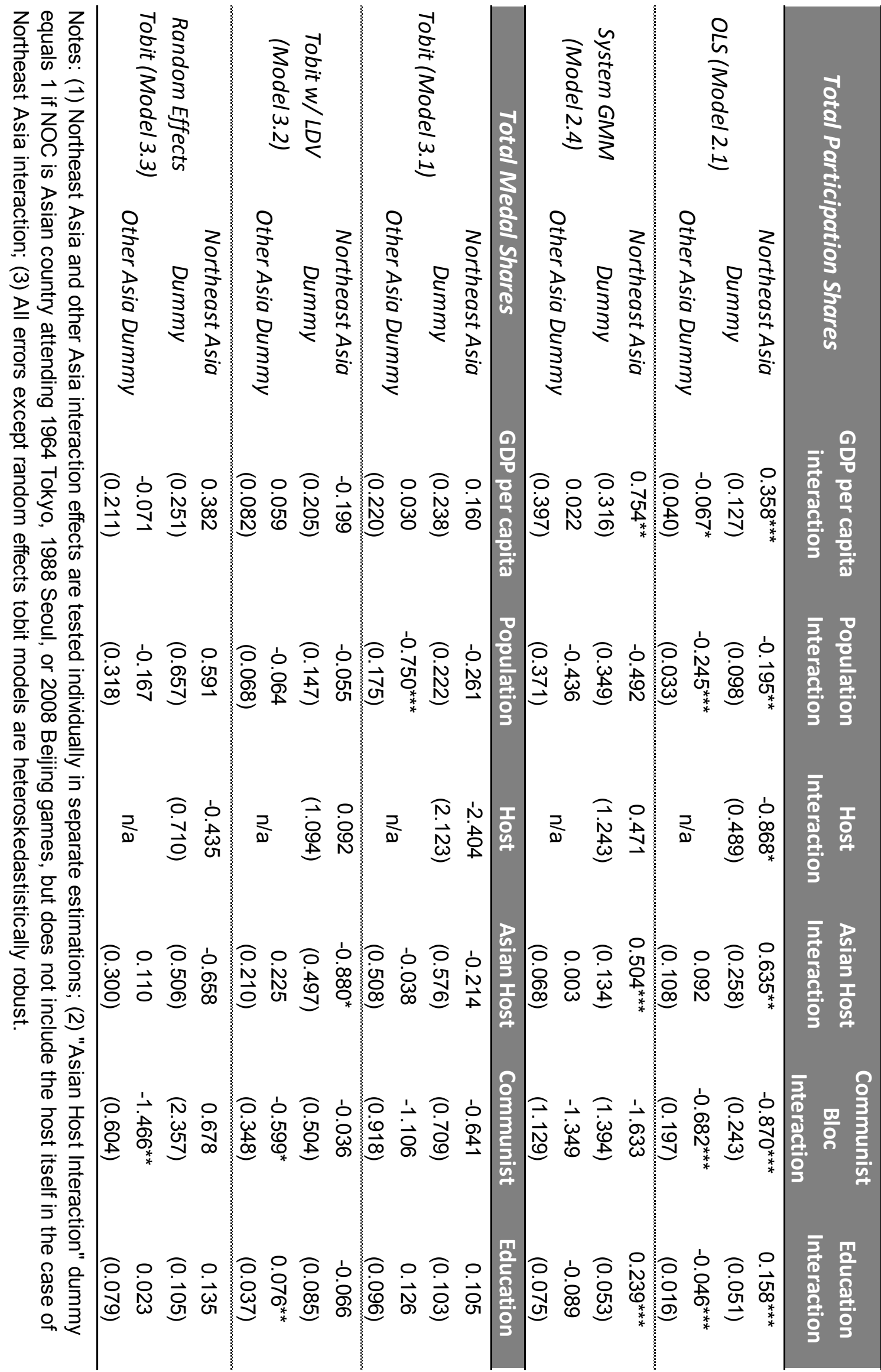


Table 6. Determinants of success for female athletes at the Summer Olympic Games

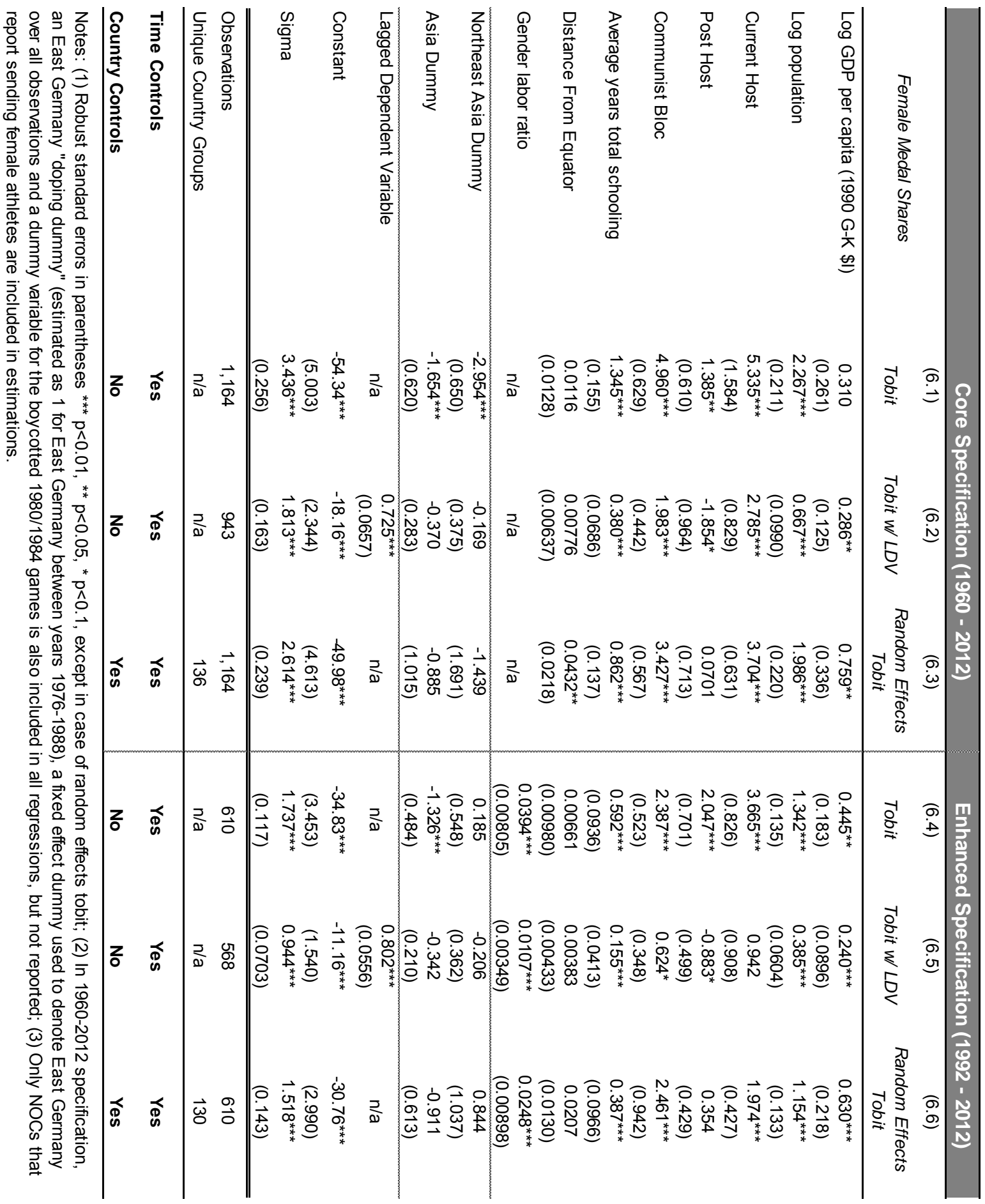


Table 7. Asian NOC success in individual sporting categories at the Summer Games, 1960 - 2012

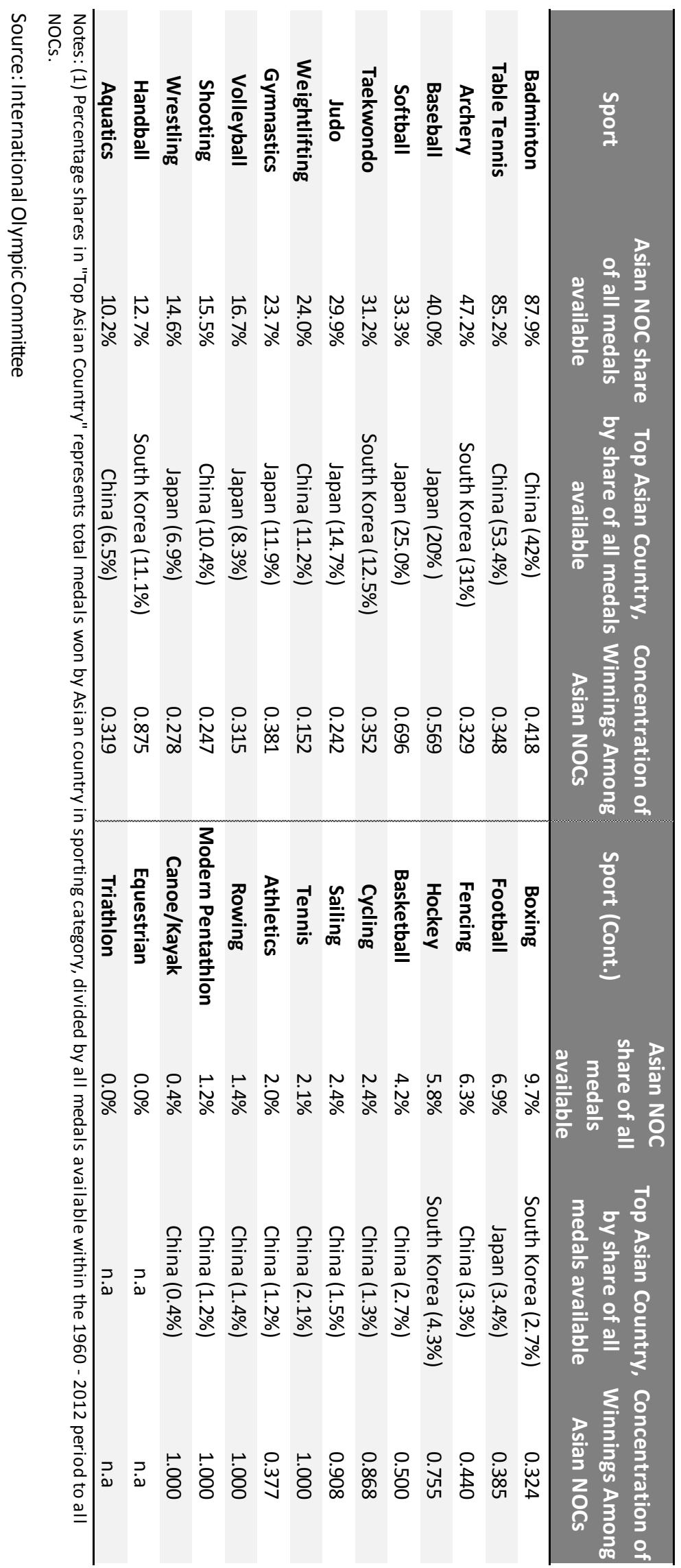


Table 8. Determinants of success for weight class-based sports

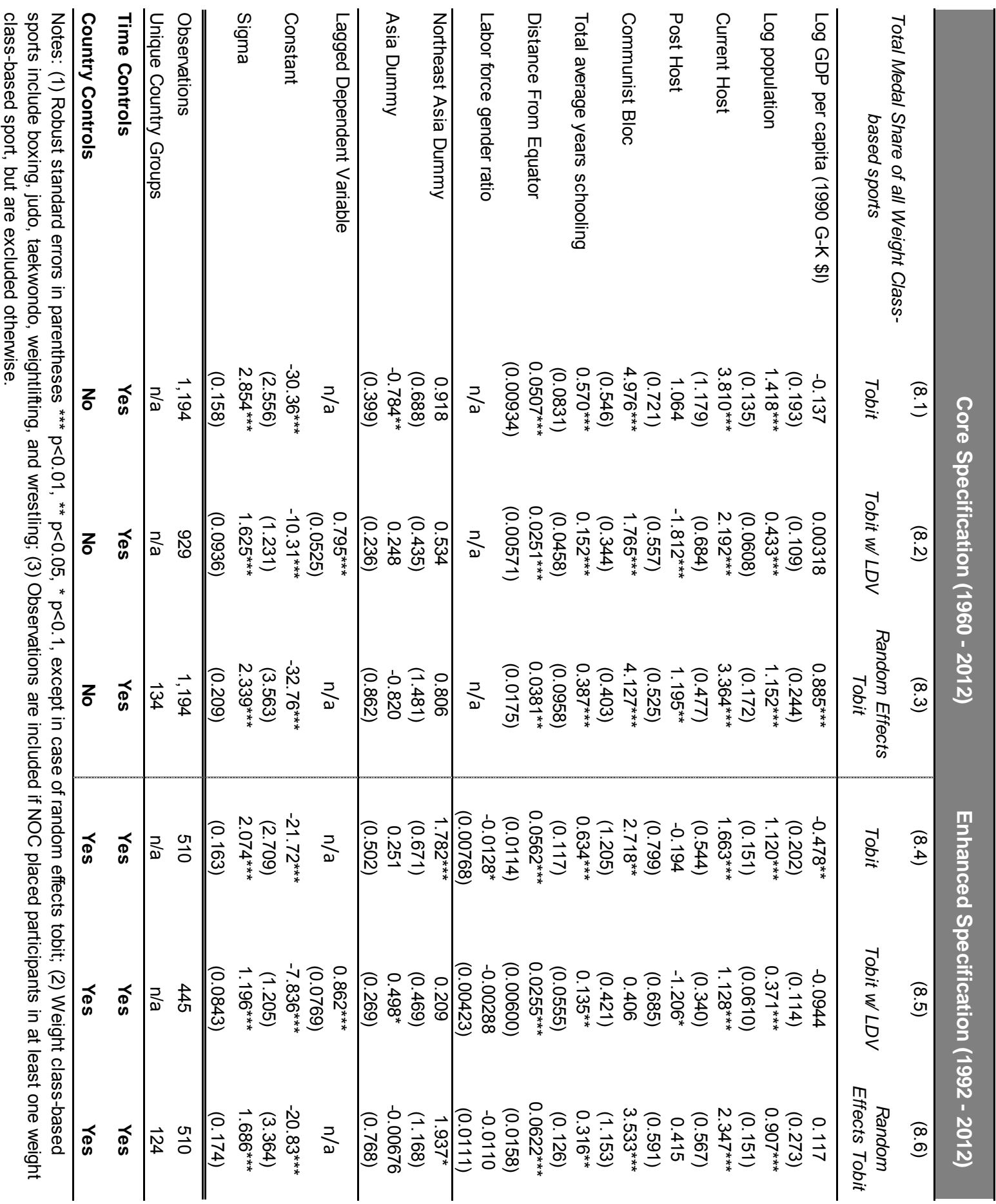


Table 9. Asia and Northeast Asia dummy coefficients in sports-specific regressions

\begin{tabular}{cccccc}
\hline Sport & \multicolumn{2}{c}{ Other Asia Dummy } & Northeast Asia Dummy & $\begin{array}{c}\text { Total } \\
\text { Observations in } \\
\text { Regression }\end{array}$ \\
\hline Aquatics & $-3.889^{* * *}$ & $(0.997)$ & $-0.279^{*}$ & $(0.153)$ & 1,001 \\
Archery & 0.458 & $(0.850)$ & $2.032^{* * *}$ & $(0.304)$ & 369 \\
Athletics & $-3.933^{* * *}$ & $(0.721)$ & $-2.075^{* * *}$ & $(0.181)$ & 1,353 \\
Badminton & $2.653^{* * *}$ & $(0.578)$ & $4.221^{* * *}$ & $(0.683)$ & 215 \\
Boxing & -0.223 & $(0.280)$ & $-1.118^{* * *}$ & $(0.308)$ & 854 \\
Canoe/Kayak & $-13.77^{* * *}$ & $(0.485)$ & $-3.699^{* * *}$ & $(0.617)$ & 483 \\
Cycling & $-2.490^{* *}$ & $(0.997)$ & $-2.192^{* * *}$ & $(0.343)$ & 680 \\
Fencing & $-15.13^{* * *}$ & $(0.421)$ & $-2.071^{* * *}$ & $(0.668)$ & 484 \\
Football & $-12.54^{* * *}$ & $(0.738)$ & $-1.635^{* *}$ & $(0.827)$ & 232 \\
Gymnastics & $-14.26^{* * *}$ & $(0.440)$ & $0.539^{*}$ & $(0.281)$ & 442 \\
Judo & -0.766 & $(0.564)$ & $1.176^{* * *}$ & $(0.178)$ & 690 \\
Modern Pentathlon & $-11.48^{* * *}$ & $(1.026)$ & $-2.876^{* * *}$ & $(0.835)$ & 300 \\
Rowing & $-14.52^{* * *}$ & $(0.359)$ & $-2.277^{* * *}$ & $(0.396)$ & 538 \\
Sailing & $-2.940^{* * *}$ & $(1.006)$ & $-1.645^{* * *}$ & $(0.354)$ & 612 \\
Shooting & $-1.944^{* * *}$ & $(0.742)$ & -0.0530 & $(0.196)$ & 879 \\
Table Tennis & $3.463^{* * *}$ & $(0.936)$ & $4.298^{* * *}$ & $(0.730)$ & 309 \\
Taekwondo & 0.349 & $(0.368)$ & 0.461 & $(0.463)$ & 214 \\
Tennis & $-14.83^{* * *}$ & $(0.402)$ & $-2.684^{* * *}$ & $(0.705)$ & 301 \\
Volleyball & $-14.36^{* * *}$ & $(1.125)$ & $-0.745^{*}$ & $(0.416)$ & 243 \\
Weightlifting & 0.518 & $(0.321)$ & -0.0640 & $(0.245)$ & 700 \\
Wrestling & -0.577 & $(0.523)$ & 0.144 & $(0.261)$ & 657 \\
\hline
\end{tabular}

Notes: Each regression uses Poisson estimation and does not contain lagged dependent variables; (2) Equestrian and triathlon, where no Asian country has won a medal between 1960 - 2012, is not shown; (3) Baseball, softball, handball, basketball, and hockey not shown due to limited number of available observations. 
Table 10. Forecasted medal shares and absolute changes for Asian countries at the 2016 Rio de Janeiro Games

\begin{tabular}{|c|c|c|c|c|}
\hline Country & $\begin{array}{r}\text { NOC Share of } \\
\text { Availa } \\
\text { London } 2012 \\
\text { Actual } \\
\end{array}$ & $\begin{array}{l}\text { tal Medals } \\
\text { (\%) } \\
\text { Rio } 2016 \\
\text { (Model- } \\
\text { weighted } \\
\end{array}$ & $\begin{array}{c}\text { Absolute } \\
\text { Percent } \\
\text { Change } \\
\text { Medals Won }\end{array}$ & $\begin{array}{c}\text { Absolute Total } \\
\text { Change Medals } \\
\text { Won }\end{array}$ \\
\hline Cambodia & 0 & 0 & 0 & 0 \\
\hline China & 9.1 & 9.37 & 0.22 & 2 \\
\hline Hong Kong & 0.1 & 0.06 & -0.04 & 0 \\
\hline Indonesia & 0.2 & 0.13 & -0.08 & -1 \\
\hline Japan & 4.0 & 4.29 & 0.34 & 3 \\
\hline Laos & 0.0 & 0 & 0 & 0 \\
\hline Malaysia & 0.2 & 0.17 & -0.04 & 0 \\
\hline Mongolia & 0.5 & 0.00 & -0.52 & -5 \\
\hline Myanmar & 0 & 0 & 0 & 0 \\
\hline Nepal & 0 & 0 & 0 & 0 \\
\hline Philippines & 0 & 0 & 0 & 0 \\
\hline Singapore & 0.2 & 0 & -0.21 & -2 \\
\hline Republic of Korea & 2.9 & 3.28 & 0.37 & 4 \\
\hline Taiwan & 0.2 & 0.41 & 0.20 & 2 \\
\hline Thailand & 0.3 & 0.25 & -0.06 & -1 \\
\hline Vietnam & 0 & 0.29 & 0.29 & 3 \\
\hline
\end{tabular}

Notes: (1) Timor-Leste and North Korea not included due to missing data; (2) Model predicted from coefficients derived from a weighted combination of specification 3.2 and a modified version of 3.5, which excludes labor force ratio and immigration stock variables; (3) For this excercise, we assume that 962 medals are available at the 2016 Games. 
Table 11. Forecasted rankings for Asian countries at the 2016 Rio de Janeiro Games

\begin{tabular}{|c|c|c|c|}
\hline NOC & $\begin{array}{l}\text { Actual Total Medals } \\
\text { Rank at London } 2012\end{array}$ & NOC & $\begin{array}{c}\text { Predicted Total } \\
\text { Medals Rank in } \\
2016 \\
\end{array}$ \\
\hline \multicolumn{4}{|c|}{ Top 20 NOCs } \\
\hline United States of America & 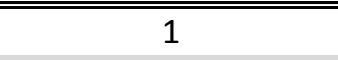 & United States of America & 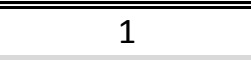 \\
\hline PR China & 2 & PR China & 2 \\
\hline Russian Federation & 3 & Russian Federation & 3 \\
\hline Great Britain & 4 & Great Britain & 4 \\
\hline Germany & 5 & Germany & 5 \\
\hline Japan & 6 & Japan & 6 \\
\hline Australia & 7 & France & 7 \\
\hline France & 8 & Australia & 8 \\
\hline Republic of Korea & 9 & Brazil & 9 \\
\hline Italy & 9 & Republic of Korea & 10 \\
\hline Netherlands & 11 & Italy & 11 \\
\hline Ukraine & 11 & Canada & 12 \\
\hline Canada & 13 & Netherlands & 13 \\
\hline Hungary & 13 & Ukraine & 14 \\
\hline Brazil & 15 & Spain & 15 \\
\hline Spain & 15 & Hungary & 16 \\
\hline New Zealand & 17 & Kazakhstan & 17 \\
\hline Kazakhstan & 17 & New Zealand & 18 \\
\hline Islamic Republic of Iran & 19 & Islamic Republic of Iran & 19 \\
\hline Jamaica & 19 & Poland & 20 \\
\hline \multicolumn{4}{|c|}{ Other Asian Countries } \\
\hline Mongolia & 32 & Chinese Taipei & 39 \\
\hline Thailand & 42 & Vietnam & 43 \\
\hline Malaysia & 47 & Thailand & 45 \\
\hline Chinese Taipei & 47 & Malaysia & 48 \\
\hline Indonesia & 47 & Indonesia & 51 \\
\hline Hong Kong & 58 & Hong Kong & 59 \\
\hline Laos & $n / a$ & Laos & $n / a$ \\
\hline Vietnam & $n / a$ & Mongolia & $n / a$ \\
\hline Philippines & $n / a$ & Philippines & $n / a$ \\
\hline Singapore & $n / a$ & Singapore & $n / a$ \\
\hline Myanmar & $n / a$ & Myanmar & $n / a$ \\
\hline Nepal & $n / a$ & Nepal & $n / a$ \\
\hline Cambodia & $n / a$ & Cambodia & $n / a$ \\
\hline
\end{tabular}

Notes: (1) Model predicted from coefficients derived from a weighted combination of specification 3.2 and a modified version of 3.5, which excludes labor force ratio and immigration stock variables; (2) In both columns, rankings reflect same sample of countries where all necessary control data is available, and do not necessarily reflect rankings of full selection of NOCs; (4) n/a reflects cases in which NOC won zero medals in actual 2012 results, and in cases where the predicted latent variable was below zero in 2016 predictions; (5) In cases of ties, NOCs receive the same ranking. 
Appendix 1. List of Asian country participants at the Summer and Winter Olympics

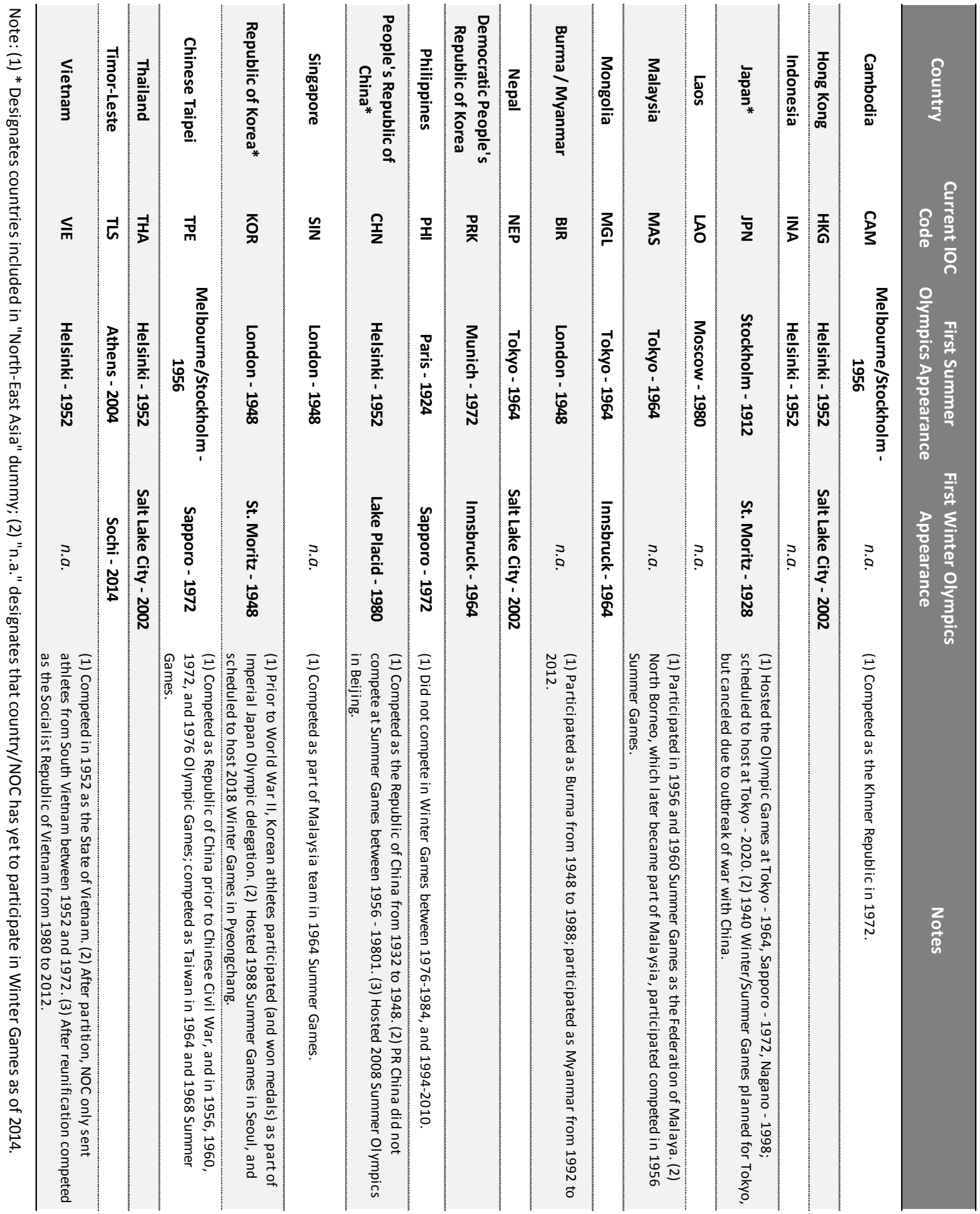


Appendix Table 2. Correlates of success at the Summer and Winter Games, 1960 -2012

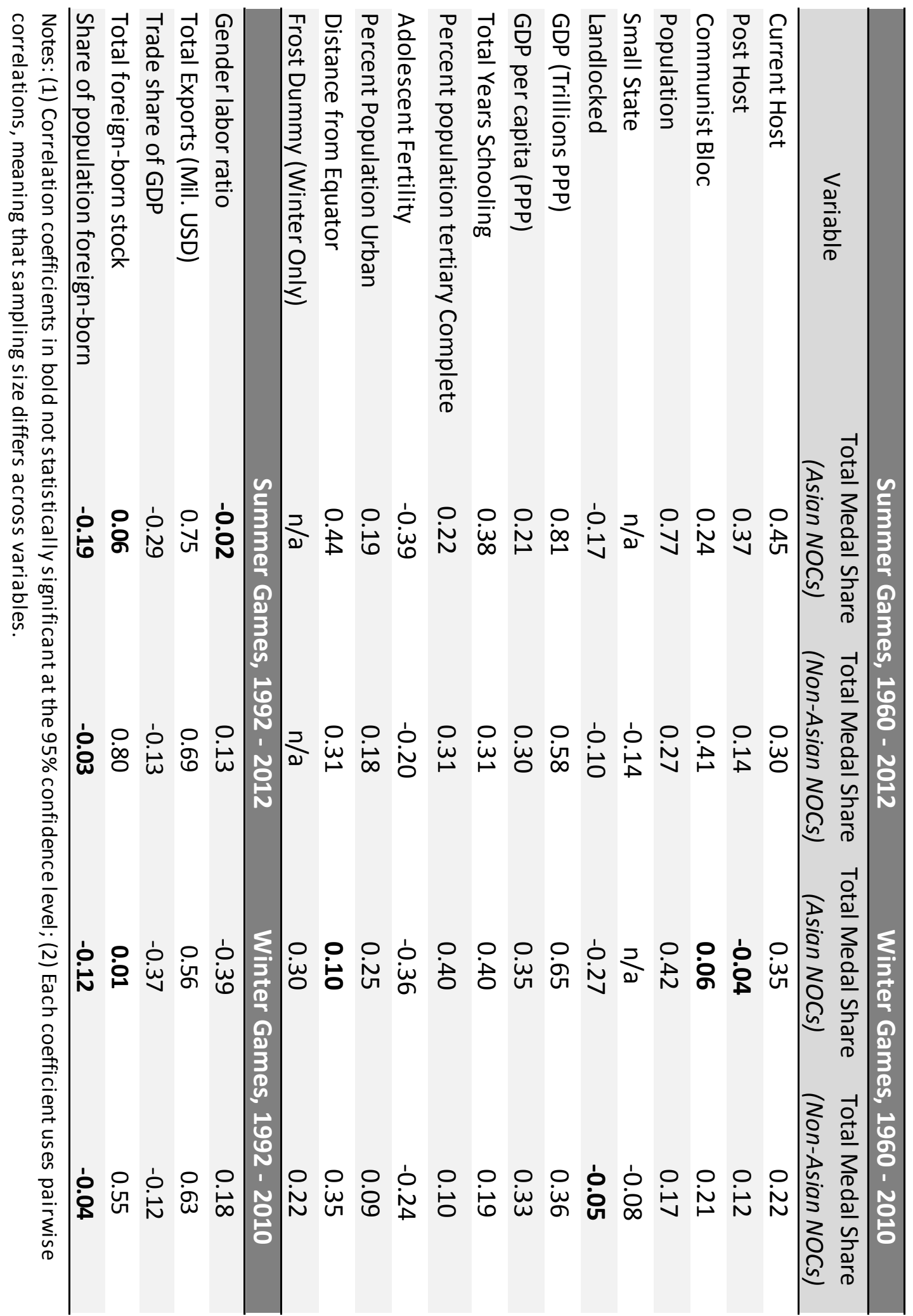




\section{Appendix Table 3. Real versus predicted medal shares in 2012 by sporting category}

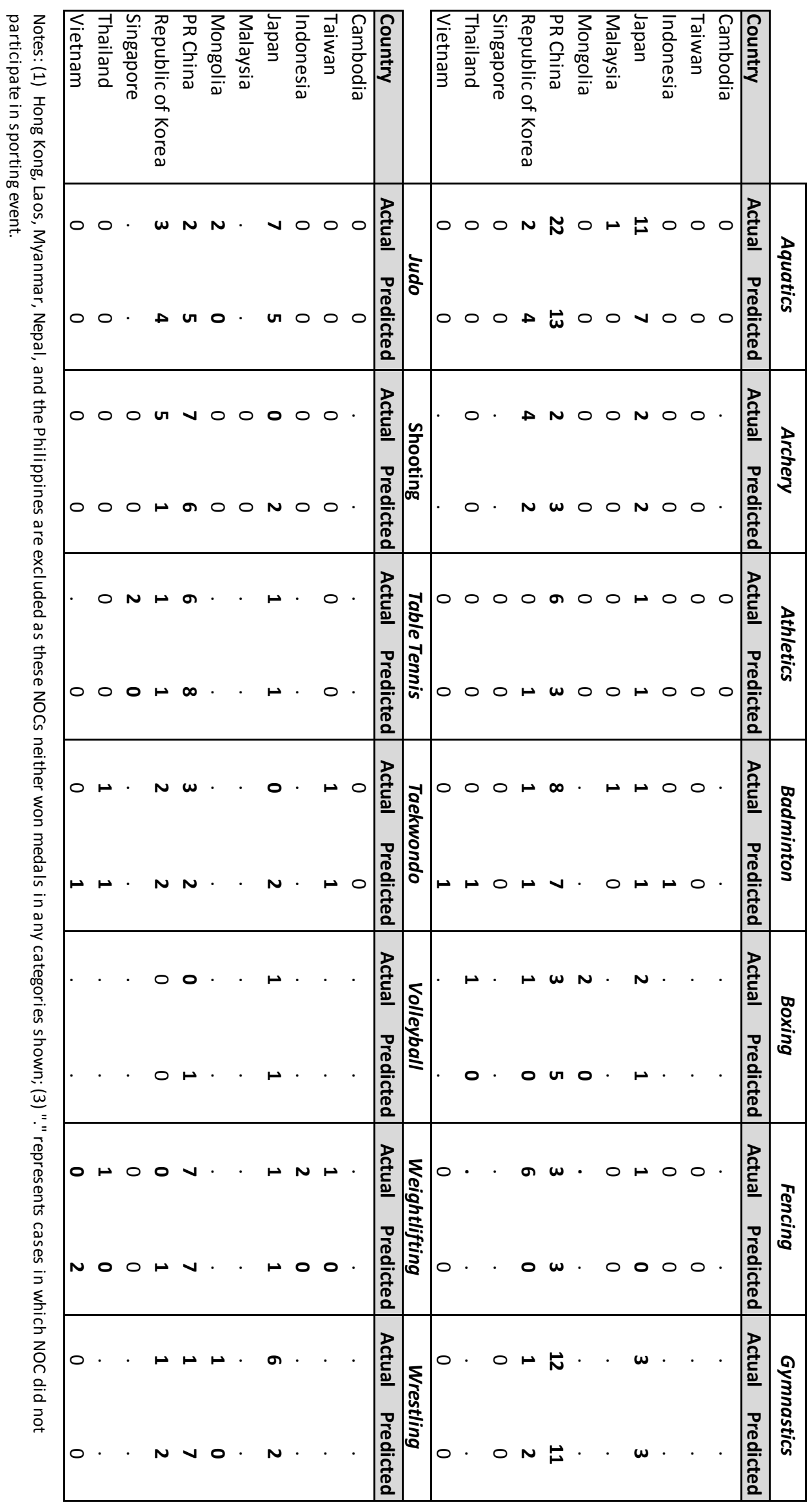

